\title{
Rationale and Plan for Vitamin D Food Fortification: A Review and Guidance Paper
}

OPEN ACCESS

Edited by:

GianLuca Colussi,

Università degli Studi di Udine, Italy

Reviewed by:

Colin Guy Scanes,

University of Arkansas, United States

Andrew S. Day,

University of Otago, New Zealand

*Correspondence:

Stefan Pilz

stefan.pilz@medunigraz.at;

stefan.pilz@chello.at

tThese authors have contributed equally to this work and are co first

authors.

Specialty section:

This article was submitted to

Systems and Translational

Endocrinology,

a section of the journal

Frontiers in Endocrinology

Received: 02 May 2018

Accepted: 21 June 2018

Published: 17 July 2018

Citation:

Pilz S, März W, Cashman KD,

Kiely ME, Whiting SJ, Holick MF Grant WB, Pludowski P, Hiligsmann M, Trummer C, Schwetz V, Lerchbaum E, Pandis M, Tomaschitz A, Grübler MR

Gaksch M, Verheyen N, Hollis BW,

Rejnmark L, Karras SN, Hahn A,

Bischoff-Ferrari HA, Reichrath J,

Jorde R, Elmadfa I, Vieth $R$, Scragg $R$,

Calvo MS, van Schoor NM,

Bouillon R, Lips P, Itkonen ST,

Martineau AR, Lamberg-Allardt $C$ and

Zittermann A (2018) Rationale and Plan for Vitamin D Food Fortification: A

Review and Guidance Paper.

Front. Endocrinol. 9:373.

doi: 10.3389/fendo.2018.00373
Stefan Pilz ${ }^{1 \star t}$, Winfried März ${ }^{2,3 \dagger}$, Kevin D. Cashman ${ }^{4}$, Mairead E. Kiely ${ }^{4}$, Susan J. Whiting ${ }^{5}$, Michael F. Holick ${ }^{6}$, William B. Grant ${ }^{7}$, Pawel Pludowski ${ }^{8}$, Mickael Hiligsmann ${ }^{9}$, Christian Trummer ${ }^{1}$, Verena Schwetz ${ }^{1}$, Elisabeth Lerchbaum ${ }^{1}$, Marlene Pandis ${ }^{1}$, Andreas Tomaschitz ${ }^{10}$, Martin R. Grübler ${ }^{11}$, Martin Gaksch ${ }^{12}$, Nicolas Verheyen ${ }^{13}$, Bruce W. Hollis ${ }^{14}$, Lars Rejnmark ${ }^{15}$, Spyridon N. Karras ${ }^{16}$, Andreas Hahn ${ }^{17}$, Heike A. Bischoff-Ferrari ${ }^{18}$, Jörg Reichrath ${ }^{19}$, Rolf Jorde ${ }^{20}$, Ibrahim Elmadfa ${ }^{21}$, Reinhold Vieth ${ }^{22}$, Robert Scragg ${ }^{23}$, Mona S. Calvo ${ }^{24}$, Natasja M. van Schoor ${ }^{25}$, Roger Bouillon ${ }^{26}$, Paul Lips ${ }^{27}$, Suvi T. Itkonen ${ }^{28}$, Adrian R. Martineau ${ }^{29}$, Christel Lamberg-Allardt ${ }^{28}$ and Armin Zittermann ${ }^{30}$

${ }^{1}$ Division of Endocrinology and Diabetology, Department of Internal Medicine, Medical University of Graz, Graz, Austria, ${ }^{2}$ Clinical Institute of Medical and Chemical Laboratory Diagnostics, Medical University of Graz, Graz, Austria, ${ }^{3}$ Synlab Academy, Synlab Services GmbH, Mannheim, Germany, ${ }^{4}$ Cork Centre for Vitamin D and Nutrition Research, School of Food and Nutritional Sciences, University College Cork, Cork, Ireland, ${ }^{5}$ College of Pharmacy and Nutrition, University of Saskatchewan, Saskatoon, SK, Canada, ${ }^{6}$ Section of Endocrinology, Nutrition and Diabetes, Department of Medicine, Physiology and Biophysics, Boston University Medical Center, Boston, MA, United States, ${ }^{7}$ Sunlight, Nutrition and Health Research Center, San Francisco, CA, United States, ${ }^{8}$ Department of Biochemistry, Radioimmunology and Experimental Medicine, The Children's Memorial Health Institute, Warsaw, Poland, ${ }^{9}$ Department of Health Services Research, CAPHRI Care and Public Health Research Institute, Maastricht University, Maastricht, Netherlands, ${ }^{10}$ Bad Gleichenberg Clinic, Bad Gleichenberg, Austria, " Department of Cardiology, Swiss Cardiovascular Center Bern, Bern University Hospital, Bern, Switzerland, ${ }^{12}$ Department of Laboratory Medicine, Paracelsus Medical University, Salzburg, Austria, ${ }^{13}$ Division of Cardiology, Department of Internal Medicine, Medical University of Graz, Graz, Austria, ${ }^{14}$ Department of Pediatrics, Medical University of South Carolina, Charleston, SC, United States, ${ }^{15}$ Department of Endocrinology and Internal Medicine, Aarhus University Hospital, Aarhus, Denmark, ${ }^{16}$ Division of Endocrinology and Metabolism, First Department of Internal Medicine, Medical School, Aristotle University of Thessaloniki, AHEPA Hospital, Thessaloniki, Greece, ${ }^{17}$ Institute of Food Science and Human Nutrition, Leibniz University Hannover, Hannover, Germany, ${ }^{18}$ Department of Geriatrics and Aging Research, University Hospital Zurich and Waid City Hospital, University of Zurich, Zurich, Switzerland, ${ }^{19}$ Center for Clinical and Experimental Photodermatology, The Saarland University Hospital, Homburg, Germany, ${ }^{20}$ Tromsø Endocrine Research Group, Department of Clinical Medicine, UiT The Arctic University of Norway, Tromsø, Norway, ${ }^{21}$ Department of Nutritional Sciences, Faculty of Life Sciences, University of Vienna, Vienna, Austria, ${ }^{22}$ Department of Nutritional Sciences, University of Toronto, Toronto, ON, Canada, ${ }^{23}$ School of Population Health, University of Auckland, Auckland, New Zealand, ${ }^{24}$ U.S. Food and Drug Administration, Silver Spring, MD, United States, ${ }^{25}$ Department of Epidemiology and Biostatistics, Amsterdam Public Health Research Institute, VU University Medical Center, Amsterdam, Netherlands, ${ }^{26}$ Laboratory of Clinical and Experimental Endocrinology, Department of Chronic Diseases, Metabolism and Ageing, KU Leuven, Leuven, Belgium, ${ }^{27}$ Endocrine Section, Department of Internal Medicine, VU University Medical Center, Amsterdam, Netherlands, ${ }^{28} \mathrm{Calcium}$ Research Unit, Department of Food and Nutrition, University of Helsinki, Helsinki, Finland, ${ }^{29}$ Barts and The London School of Medicine and Dentistry, Queen Mary University of London, London, United Kingdom, ${ }^{30}$ Clinic for Thoracic and Cardiovascular Surgery, Heart Center North Rhine-Westfalia, Ruhr University Bochum, Bad Oeynhausen, Germany

Vitamin D deficiency can lead to musculoskeletal diseases such as rickets and osteomalacia, but vitamin D supplementation may also prevent extraskeletal diseases such as respiratory tract infections, asthma exacerbations, pregnancy complications and premature deaths. Vitamin D has a unique metabolism as it is mainly obtained through synthesis in the skin under the influence of sunlight (i.e., ultraviolet-B radiation) whereas intake by nutrition traditionally plays a relatively minor role. Dietary guidelines for vitamin $D$ are based on a consensus that serum 25-hydroxyvitamin $D(25[\mathrm{OH}] \mathrm{D})$ 
concentrations are used to assess vitamin $\mathrm{D}$ status, with the recommended target concentrations ranging from $\geq 25$ to $\geq 50 \mathrm{nmol} / \mathrm{L}(\geq 10-\geq 20 \mathrm{ng} / \mathrm{mL})$, corresponding to a daily vitamin $D$ intake of 10 to $20 \mu \mathrm{g}$ (400-800 international units). Most populations fail to meet these recommended dietary vitamin $D$ requirements. In Europe, 25(OH)D concentrations $<30 \mathrm{nmol} / \mathrm{L}(12 \mathrm{ng} / \mathrm{mL})$ and $<50 \mathrm{nmol} / \mathrm{L}(20 \mathrm{ng} / \mathrm{mL})$ are present in 13.0 and $40.4 \%$ of the general population, respectively. This substantial gap between officially recommended dietary reference intakes for vitamin $D$ and the high prevalence of vitamin $\mathrm{D}$ deficiency in the general population requires action from health authorities. Promotion of a healthier lifestyle with more outdoor activities and optimal nutrition are definitely warranted but will not erase vitamin D deficiency and must, in the case of sunlight exposure, be well balanced with regard to potential adverse effects such as skin cancer. Intake of vitamin D supplements is limited by relatively poor adherence (in particular in individuals with low-socioeconomic status) and potential for overdosing. Systematic vitamin D food fortification is, however, an effective approach to improve vitamin D status in the general population, and this has already been introduced by countries such as the US, Canada, India, and Finland. Recent advances in our knowledge on the safety of vitamin $D$ treatment, the dose-response relationship of vitamin $D$ intake and 25(OH)D levels, as well as data on the effectiveness of vitamin D fortification in countries such as Finland provide a solid basis to introduce and modify vitamin D food fortification in order to improve public health with this likewise cost-effective approach.

Keywords: vitamin D, public health, food fortification, general population, guidelines, evidence, recommendations, policy

\section{INTRODUCTION}

Vitamin D deficiency is common worldwide and potential adverse effects of a poor vitamin $D$ status are of concern for public health (1-4). In this review, we aim to provide an overview on the rationale, current status and implementation plans for vitamin $\mathrm{D}$ food fortification as a means to close the gap between widespread inadequate vitamin $\mathrm{D}$ intakes and the target vitamin $\mathrm{D}$ intakes as recommended by nutritional vitamin $\mathrm{D}$ guidelines (4-8). This work should ideally provide a basis for the communication with and guidance for health authorities and regulators that are responsible for food policy and potential food fortification within their respective countries or regions.

This paper is based on a systematic literature search in PubMed until the end of March 2018 using the search terms "vitamin D" and "fortification," but reference lists of retrieved articles and personal references were also used. After an introduction on metabolism and clinical effects of vitamin D, we briefly summarize major nutritional vitamin $\mathrm{D}$ guidelines and give an overview on global vitamin $\mathrm{D}$ status and vitamin $\mathrm{D}$ intakes with a focus on the gap that exists between current estimates for vitamin $\mathrm{D}$ requirements and actual vitamin D intakes within populations. Following a section on general approaches on how to prevent and treat vitamin D deficiency, we outline safety issues of vitamin D before we present data on the history and the current status of vitamin $\mathrm{D}$ food fortification world-wide. Then, we briefly summarize the approaches and modeling as well as cost-effectiveness studies of vitamin D food fortification. Finally, we present some suggestions and guidance on how to implement vitamin $\mathrm{D}$ food fortification.

\section{METABOLISM OF VITAMIN D}

Vitamin $\mathrm{D}$ has a unique metabolism and is mainly produced in the skin where exposure to ultraviolet-B (UV-B) radiation (in sunlight) induces the conversion of skin produced 7 dehydrocholesterol into vitamin $\mathrm{D}_{3}$ (cholecalciferol) (9). Dietary intake of vitamin $\mathrm{D}$ from natural foods traditionally plays only a minor role with few available natural sources: animal sources such as fatty fish, cod liver oil, or egg yolks contain vitamin $\mathrm{D}_{3}$, and fungal sources such as mushrooms and yeast exposed to sunlight or $\mathrm{UV}$ radiation contain vitamin $\mathrm{D}_{2}$ (ergocalciferol). Vitamin $\mathrm{D}_{3}$ and $\mathrm{D}_{2}$ share, in general, the same metabolism. Therefore, we will not differentiate between these two forms unless otherwise stated and refer to vitamin $\mathrm{D}$ (meaning vitamin $\mathrm{D}_{3}$ and/or vitamin $\mathrm{D}_{2}$ ) throughout this manuscript. In terms of sources, vitamin D can also be supplied by supplements and fortified foods but vitamin D and its metabolites may also be stored and released from the body's adipose tissue (9-11). A very rough general estimate is that about $80 \%$ of vitamin D supply comes from UV-B induced production in the skin and about $20 \%$ from dietary intake, but this varies considerably depending on factors such as season/sun exposure habits, latitude, nutrition/supplement intake or ethnicity (3, 9 , 12). Despite a high degree of inheritance of serum 25hydroxyvitamin D $(25[\mathrm{OH}] \mathrm{D})$ in twin studies, data from a 
Genome Wide Association Study (GWAS) indicate that serum $25(\mathrm{OH}) \mathrm{D}$ concentrations have only a modest overall heritability due to common GWAS single nucleotide polymorphisms (SNPs) of $7.5 \%$, highlighting the great impact of non-genetic factors to the variability in serum $25(\mathrm{OH}) \mathrm{D}$ concentrations $(13,14)$.

Vitamin D itself does not exert significant genomic biological effects and has to be metabolized (9). The common metabolism of vitamin $\mathrm{D}$ from any source involves, as a first step, the conversion to $25(\mathrm{OH}) \mathrm{D}$ in the liver that is mediated by different 25 hydroxylase enzymes (9). Serum $25(\mathrm{OH}) \mathrm{D}$ is the main circulating vitamin $\mathrm{D}$ metabolite that is considered to best indicate overall vitamin $\mathrm{D}$ status as it reflects vitamin $\mathrm{D}$ supply from diverse sources. Serum $25(\mathrm{OH}) \mathrm{D}$ has a traced half-life of approximately 2-3 weeks, whereas vitamin D itself has a half-life of only 1 day. In the bloodstream, approximately 85 to $90 \%$ of $25(\mathrm{OH}) \mathrm{D}$ is bound to vitamin D binding protein (DBP) and 10 to $15 \%$ is bound to albumin, so that less than $1 \%$ of serum $25(\mathrm{OH}) \mathrm{D}$ is unbound or free (15). The classification of vitamin D status is currently based on total serum $25(\mathrm{OH}) \mathrm{D}$ concentrations, i.e., the sum of bound and free fractions of both $25(\mathrm{OH}) \mathrm{D}_{2}$ and $25(\mathrm{OH}) \mathrm{D}_{3}$. It should, however, be acknowledged that there is some discussion regarding whether measuring free $25(\mathrm{OH}) \mathrm{D}$ concentrations may also be useful $(15,16)$. Such considerations are based on the fact that free $25(\mathrm{OH}) \mathrm{D}$ may cross the plasma membrane due to its lipophilic properties, whereas only a few organs that are crucial for vitamin D effects such as the kidneys, the parathyroid glands and the placenta are able to take up DBP-bound vitamin D metabolites through endocytosis by the megalin/cubilin complex $(15,16)$. While this is an active scientific debate, it is well established that $25(\mathrm{OH}) \mathrm{D}$ per se is hardly biologically active and has to undergo a further hydroxylation step that takes mainly place in the kidneys. In detail, renal 1-alpha-hydroxylase (CYP27B1) converts $25(\mathrm{OH}) \mathrm{D}$ to 1,25 dihydroxyvitamin $\mathrm{D}(1,25[\mathrm{OH}] 2 \mathrm{D})$ that is also called "calcitriol" or the "active vitamin D hormone." Whereas the rate of 25hydroxylation in the liver is mainly substrate dependent until a plateau is reached at high serum $25(\mathrm{OH}) \mathrm{D}$ concentrations, 1-alpha hydroxylation in the kidneys is under tight control by calcium and phosphate metabolism including parathyroid hormone $(\mathrm{PTH})$, which stimulates 1-alpha-hydroxylation and fibroblast growth factor-23 (FGF-23), which inhibits it.

From a physiological perspective, $1,25(\mathrm{OH}) 2 \mathrm{D}$ functions like a classic steroid hormone (similar to sex or thyroid hormones): after binding of $1,25(\mathrm{OH}) 2 \mathrm{D}$ to the vitamin $\mathrm{D}$ receptor (VDR), this complex translocates to the cell nucleus and regulates the expression of hundreds of genes by interacting with its vitamin D responsive elements on the DNA. Whereas serum 1,25(OH)2D levels mainly derive from the kidneys and therefore exert classic endocrine functions, there is also a wide expression of extrarenal 1-alpha-hydroxylase that converts $25(\mathrm{OH}) \mathrm{D}$ to $1,25(\mathrm{OH}) 2 \mathrm{D}$ on a local/tissue level thereby contributing to autocrine and paracrine functions of $1,25(\mathrm{OH}) 2 \mathrm{D}$. Importantly, the expression of VDR in almost all human tissues provides a sound scientific basis to postulate that vitamin D is important for overall human health. Further metabolism and degradation of vitamin $\mathrm{D}$ metabolites is initiated by 24-hydroxylase (CYP24A1), and after additional hydroxylation and oxidation steps, the resulting water soluble metabolites, one of which is calcitroic acid, are finally excreted in the bile and urine. For a more detailed description of vitamin $\mathrm{D}$ metabolism, we refer the reader to more detailed reviews on this topic $(9,15,17)$.

\section{CLINICAL EFFECTS OF VITAMIN D}

Vitamin D is historically known as a substance that can prevent and treat nutritional rickets and osteomalacia (18-20). Rickets is a bone disease that is associated with low serum calcium and low serum phosphate, and is characterized by widening and delay of mineralization of growth plates in bones (18-20). The clinical presentation of rickets includes heterogeneous skeletal and nonskeletal manifestations such as bowing deformities of the bones, development delay or widening of joints (18-20). Severe cases of rickets can lead to hypocalcemic complications including tetany and seizures as well as dilated cardiomyopathy which can be fatal (18-20). Whereas rickets can only occur in open growth plates, osteomalacia constitutes defective mineralization of existing bone (closed growth plates) (18-20). Rickets and osteomalacia can lead to bone deformation (e.g., pelvic deformities in girls with risk of obstructed labor), as well as isolated and global bone pain and muscle weakness (18-20). Apart from rickets and osteomalacia, vitamin D supplementation may prevent falls and fractures in older individuals at risk of vitamin $\mathrm{D}$ deficiency, but data from randomized controlled trials (RCTs) on this topic are inconsistent (21-27). This may be explained by different dosing regimens with daily dosing may be beneficial and large intermittent bolus dosing may be detrimental (21-27). Moreover, it is sometimes difficult to disentangle separate effects of vitamin $\mathrm{D}$ and calcium, as there exist interactions between them. Several RCTs with a significant benefit used a combined supplementation of calcium plus vitamin D at doses of $17.5-20 \mu \mathrm{g}(700-800$ international units, IU) per day (21-27).

Apart from skeletal effects, vitamin D may also have an impact on extra-skeletal health $(3,28-31)$. Several epidemiological studies have shown that low serum $25(\mathrm{OH}) \mathrm{D}$ concentrations are a risk marker for various diseases as well as mortality (3, 28-31) (see Figure 1 for the association between serum $25(\mathrm{OH}) \mathrm{D}$ and mortality). Data from meta-analyses of RCTs suggest that vitamin D supplementation may reduce mortality, respiratory tract infections, asthma exacerbations and pregnancy complications, but more data are required to clearly establish causality and doses-response relationships (32-41). Of particular importance are the RCT data suggesting that vitamin D supplementation during pregnancy may be useful in preventing general complications of pregnancy or infant outcomes such as asthma/wheeze $(42,43)$.

\section{NUTRITIONAL VITAMIN D GUIDELINES}

Recommendations relating to dietary vitamin $\mathrm{D}$ requirements in general populations are termed dietary reference intakes (DRI) or dietary reference values (DRV) $(5,6)$. These are based on the assumptions that total $25(\mathrm{OH}) \mathrm{D}$ serum concentrations are a biomarker of vitamin $\mathrm{D}$ status and indicate vitamin $\mathrm{D}$ intakes 


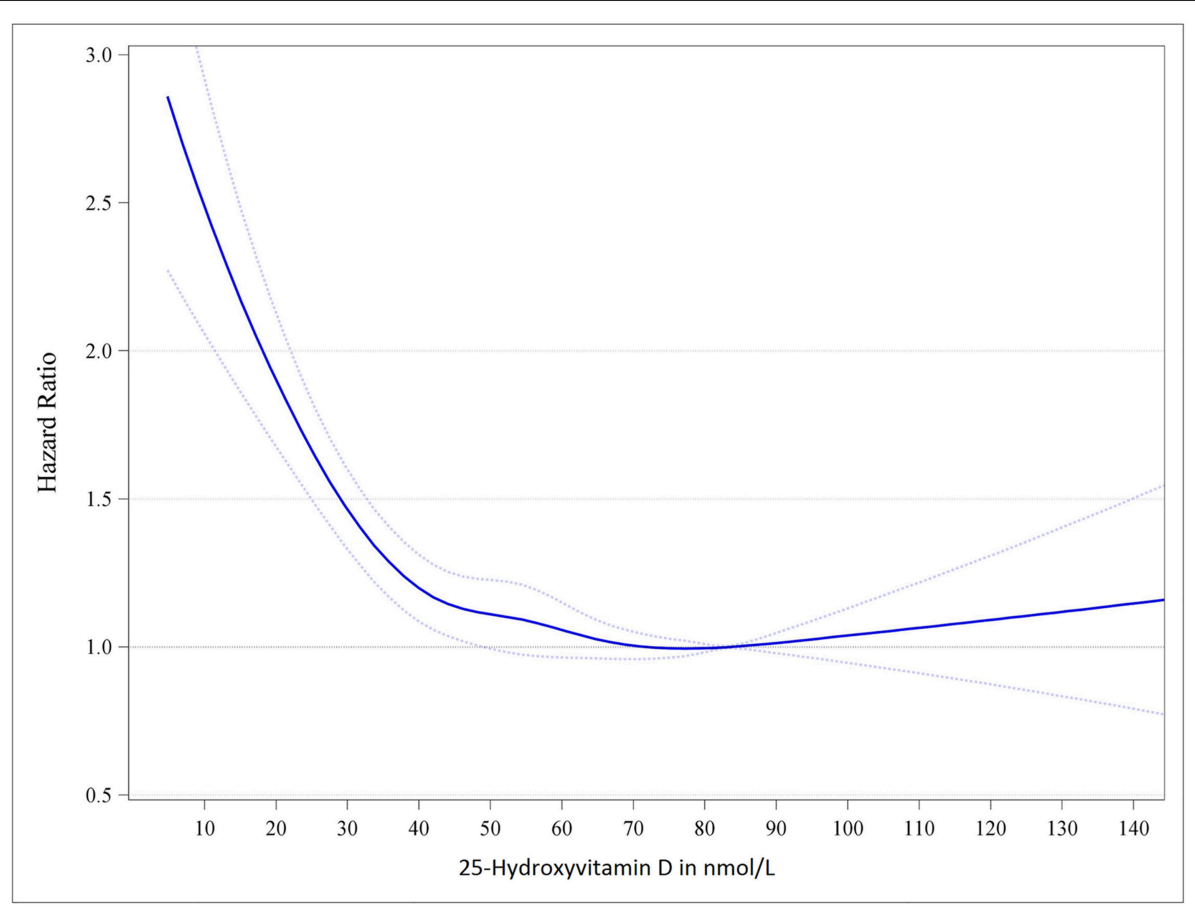

FIGURE 1 | Dose-response trend of hazard ratios of death from all causes by standardized serum 25-hydroxyvitamin D. Dose-response trend of hazard ratios of all-cause mortality by standardized 25-hydroxyvitamin D were adjusted for age, sex, body mass index and season of blood drawing concentrations. Hazard ratios (blue line with 95\% confidence intervals as dotted blue lines) are referring to the 25 -hydroxyvitamin D concentration of $83.4 \mathrm{nmol} / \mathrm{L}$ (i.e., the median 25 -hydroxyvitamin D concentration of the group with 25-hydroxyvitamin D concentration from 75 to $99.99 \mathrm{nmol} / \mathrm{L}$ ). Adopted from Gaksch et al. (28).

in the absence of cutaneous vitamin $\mathrm{D}$ production, which is especially the case in winter at northern latitudes (i.e., in regions far away from the equator). The rationale for nutritional vitamin $\mathrm{D}$ recommendations is the establishment of a cause and effect relationship between vitamin $\mathrm{D}$ intake and specified health outcomes. To date, vitamin D guidelines have generally been based on beneficial effects of vitamin D on musculoskeletal health outcomes (e.g., rickets, osteomalacia, fractures, muscle weakness, falls etc.) and occasionally on extraskeletal health outcomes such as pregnancy-related health outcomes or mortality. The dose-response relationship is then usually characterized by the association between serum $25(\mathrm{OH}) \mathrm{D}$ concentrations and these health outcomes.

As part of this process, certain target concentrations for serum $25(\mathrm{OH}) \mathrm{D}$ are established that are then used to calculate the vitamin $\mathrm{D}$ intakes for the estimated average requirement (EAR), that is the vitamin $\mathrm{D}$ intake at the estimated median requirement, and the recommended dietary allowance (RDA), that is the vitamin $\mathrm{D}$ intake that meets or exceeds the vitamin $\mathrm{D}$ requirements of $97.5 \%$ of the population. If the evidence is insufficient to define a RDA, an adequate intake (AI), is defined. The AI is the recommended average daily intake level of a nutrient based on observed or experimentally determined approximations or estimates of intakes that are assumed to be adequate for a group of apparently healthy people. After setting the target serum $25(\mathrm{OH}) \mathrm{D}$ concentrations for the EAR/RDA/AI, the vitamin $\mathrm{D}$ intakes that are required to achieve these concentrations thresholds, under circumstances of minimal to no UV-B induced cutaneous vitamin D production, are estimated by meta-regression analyses. The DRV/DRI also assume that the requirements for other nutrients such as e.g., calcium are met. In reality, this is usually not always the case, and vitamin $\mathrm{D}$ requirements may therefore even be higher in individuals with inadequate calcium intake, and may also vary according to other factors such as body mass index, ethnicity or genetic polymorphisms related to vitamin D metabolism/effects $(13,44)$.

An excellent overview of nutritional vitamin $\mathrm{D}$ guidelines is published elsewhere (5). For the US and Canada, the Institute of Medicine (IOM) report on vitamin D and calcium was released in 2010 and is considered the benchmark for nutritional vitamin D guidelines $(45,46)$. The IOM DRI report together with the European Food Safety Authority (EFSA) DRV report can be regarded as the main nutritional vitamin D guidelines (45-47). Therefore, we list the DRV/DRI of these two main guidelines together with three of the, in our opinion, most relevant national guidelines [i.e., Scientific Advisory Committee on Nutrition (SACN)report from the UK, the report from the Nutritional Societies in Germany Austria and Switzerland (DACH) and those of the Nordic European countries (NORDEN)] in Table 1 (45-50). These recommendations are based on conditions of minimal or no endogenous vitamin D synthesis. Apart from these nutritional vitamin $\mathrm{D}$ guidelines for the general healthy population, there are also vitamin $\mathrm{D}$ guidelines or recommendations published that aim to guide vitamin D 
TABLE 1 | Dietary reference values (DRV)/dietary reference intakes (DRI) for vitamin D.

\begin{tabular}{|c|c|c|c|c|c|c|}
\hline Country (health authority) & USA & da (IOM) & $\begin{array}{l}\text { Europe } \\
\text { (EFSA) }\end{array}$ & $\begin{array}{c}\text { Germany, Austria and } \\
\text { Switzerland (DACH) }\end{array}$ & UK (SACN) & $\begin{array}{c}\text { Nordic European } \\
\text { countries (NORDEN) }\end{array}$ \\
\hline DRV/DRI & EAR & RDA & Al & Al & RNI & $\mathbf{R I}$ \\
\hline Target 25(OH)D in $\mathrm{nmol} / \mathrm{L}$ & 40 & 50 & 50 & 50 & 25 & 50 \\
\hline Age group & \multicolumn{6}{|c|}{ Vitamin $D$ intakes in $\mu \mathrm{g}$ per day ( $1 \mu \mathrm{g}=\mathbf{4 0}$ international units) } \\
\hline 0-6 months & 10 & & & 10 & $8.5-10$ & \\
\hline $7-12$ months & 10 & & 10 & 10 & $8.5-10$ & 10 \\
\hline $1-3$ years & 10 & 15 & 15 & 20 & 10 & 10 \\
\hline $4-6$ years & 10 & 15 & 15 & 20 & 10 & 10 \\
\hline $7-8$ years & 10 & 15 & 15 & 20 & 10 & 10 \\
\hline 9-10 years & 10 & 15 & 15 & 20 & 10 & 10 \\
\hline $11-14$ years & 10 & 15 & 15 & 20 & 10 & 10 \\
\hline $15-17$ years & 10 & 15 & 15 & 20 & 10 & 10 \\
\hline 18-69 years & 10 & 15 & 15 & 20 & 10 & 10 \\
\hline 70-74 years & 10 & 20 & 15 & 20 & 10 & 10 \\
\hline 75 years and older & 10 & 20 & 15 & 20 & 10 & 20 \\
\hline Pregnancy & 10 & 15 & 15 & 20 & 10 & 10 \\
\hline Lactation & 10 & 15 & 15 & 20 & 10 & 10 \\
\hline
\end{tabular}

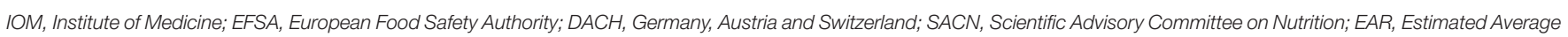
Requirement; RDA, Recommended Dietary Allowance; Al, Adequate Intake; RNI, Reference Nutrient Intake; RI, Recommended; Intake; 25(OH)D, 25-hydroxyvitamin D.

diagnostics and supplementation in patients or specific groups, an issue that is beyond the scope of the current article (51-53). A few of these guidelines recommend relatively high target serum 25(OH)D concentrations such as $75 \mathrm{nmol} / \mathrm{L}$ (divide by 2.496 to convert $\mathrm{nmol} / \mathrm{L}$ to $\mathrm{ng} / \mathrm{mL}$ ) because for some musculoskeletal health outcomes and parameters of mineral metabolism such as PTH, these levels may be optimal, whereas target serum $25(\mathrm{OH}) \mathrm{D}$ concentrations for effects on the immune system are not clearly established but may even be higher $(3,51,53)$.

\section{GLOBAL VITAMIN D STATUS AND VITAMIN D INTAKES}

Several studies have investigated the prevalence of low serum $25(\mathrm{OH}) \mathrm{D}$ concentrations and of inadequate vitamin $\mathrm{D}$ intakes in general populations worldwide (54-63). It is obvious from these various reports that serum $25(\mathrm{OH}) \mathrm{D}$ concentrations and vitamin $\mathrm{D}$ supply are insufficient to meet the vitamin $\mathrm{D}$ requirements in significant sections of the general population worldwide. There exist, of course, regional differences in the burden of vitamin $\mathrm{D}$ deficiency, but it can be clearly stated that vitamin D deficiency is a worldwide public health problem. According to recent surveys, serum 25(OH)D concentrations $<30 \mathrm{nmol} / \mathrm{L}$ and $<50 \mathrm{nmol} / \mathrm{L}$ are documented in 13.0 and $40.4 \%$ of the general population in Europe, and in 6.7 and $26.0 \%$ of the general population in the US, respectively $(55,57,58)$. Compared to Europe and North America, the prevalence of low serum 25(OH)D concentrations seems to be even higher in many low and lower-middle income countries (56). In India, Tunisia and Mongolia, for example, the prevalence of serum 25(OH)D concentrations below 25/30 $\mathrm{nmol} / \mathrm{L}$ exceeds $20 \%$ in the entire population (56). It should be noted that interpretation of some previous vitamin D status data may be limited due to differences/problems of laboratory assays, whereas many recent surveys were based on well standardized 25(OH)D measurements (55).

Data on dietary vitamin D intakes are less complete compared to data on serum $25(\mathrm{OH}) \mathrm{D}$ concentrations, but it can be generally stated that in the majority of the countries worldwide, the median vitamin D intake is below $5 \mu \mathrm{g}$ (200 IU) per day (62). It should, however, be acknowledged that assessment of vitamin $\mathrm{D}$ intakes is not trivial because food composition data are not always up-to-date with regard to actual vitamin D content of food. Furthermore, 25(OH)D content of food has often not been considered although this plays a significant role for vitamin $\mathrm{D}$ status in consideration of the fact that $25(\mathrm{OH}) \mathrm{D}_{3}$ is approximately 5 times as effective as an equivalent intake of vitamin $\mathrm{D}_{3}$ in terms of increasing serum $25(\mathrm{OH}) \mathrm{D}$ concentrations (4).

\section{APPROACHES TO PREVENTION AND TREATMENT OF VITAMIN D DEFICIENCY}

Approaches to improve vitamin D status in the population include increasing intake of naturally vitamin $\mathrm{D}$ containing food, food fortification, vitamin D supplements, increasing solar UV-B exposure and weight loss (64-76). Promotion of weight loss which may mobilize vitamin $\mathrm{D}$ and its metabolites from the adipose tissue as well as increasing intake of naturally vitamin D containing food (e.g., fatty fish) can be considered as general steps toward a healthier lifestyle but such attempts 
have usually an insufficient overall impact on vitamin D status. Nevertheless, a meta-analyses of RCTs showed that compared to controls, fish consumption, which is usually the highest food source of vitamin $\mathrm{D}$, raised serum $25(\mathrm{OH}) \mathrm{D}$ concentrations on average by $4.4 \mathrm{nmol} / \mathrm{L}$ (75). Recommendations regarding more sunlight (UV-B) exposure have the potential to increase serum 25(OH)D concentrations but are limited by adverse effects related to skin damage and skin cancer. Use of vitamin D supplements represents an effective strategy for the prevention and treatment of vitamin D deficiency at the individual level, but adherence within the general population as well as potential overdosing of vitamin D supplements are significant limitations. In the US, $3.2 \%$ in the general population take vitamin D supplements at a dose of $\geq 100 \mu \mathrm{g}$ (4,000 IU) per day (10). It should also be underlined that supplement intake positively correlates with a healthier lifestyle and higher socio-economic status suggesting that recommendations for supplement intake do not adequately reach those people at particular high risk of vitamin $\mathrm{D}$ deficiency.

Therefore, vitamin D food fortification seems to be the most appropriate way of improving vitamin D intake and status in the general population in order to meet dietary vitamin D recommendations. In general, food can be enriched with vitamin $\mathrm{D}$ by simply adding vitamin $\mathrm{D}$ to food (i.e., traditional vitamin D food fortification) or by so called "bioaddition." Bioaddition of vitamin D, which has also been called "biofortification," refers to various ways of increasing vitamin D content of food without direct exogenous addition of vitamin D. Examples of bioaddition include feeding hens with vitamin $\mathrm{D}$ (and/or 25[OH]D) to increase the vitamin $\mathrm{D}$ (and/or 25[OH]D) content of the eggs, increasing vitamin $\mathrm{D}$ content of feed for farmed fish to increase their flesh vitamin D content, likewise with livestock animals in relation to meat, and UV exposure of mushrooms or yeast (that is then used to make bread), which facilitates the conversion of ergosterol to vitamin $\mathrm{D}_{2}$. These issues are discussed in detail elsewhere $(4,74)$.

\section{SAFETY ISSUES FOR VITAMIN D}

When discussing public health strategies to increase vitamin $\mathrm{D}$ intakes in the general population, the potential dual harm of both deficiency and excess of vitamin $\mathrm{D}$ must be considered (77-83). Large oral doses of vitamin D increase serum 25(OH)D concentrations while serum 1,25(OH)2D concentrations are usually not materially changed and can even be reduced (79). It has been hypothesized that at very high serum $25(\mathrm{OH}) \mathrm{D}$ concentrations the binding capacity of the DBP may be exceeded leading to a release of free and biologically active vitamin D metabolites. Clinically, vitamin D intoxication can lead to hypercalciuria which precedes hypercalcemia. Consequences of hypercalciuria may include the formation of kidney stones, nephrocalcinosis and reduced kidney function. Hypercalcemia can be associated with fatigue, muscle weakness, weight loss, nausea, vomiting, soft tissue calcification or tachycardia. Recent RCTs using relatively high vitamin $\mathrm{D}$ doses have significantly increased our knowledge on the safety of vitamin D treatment (84-91).

Guidance on the safety of vitamin D intake is provided by several health agencies that released tolerable upper intake levels (ULs) for vitamin D as shown in Table 2. The IOM and EFSA have both set their UL for vitamin D at $100 \mu \mathrm{g}(4,000 \mathrm{IU})$ per day for adults $(45,46,78)$. Given an individual recommendation (e.g., RDA or equivalent) of $10-20 \mu \mathrm{g}$ (400-800 IU), the safety range is $80-90 \mu \mathrm{g}(3,200-3,600 \mathrm{IU})$ and the safety factor (UL/RDA) is $5-10$. The EFSA report on ULs, after reviewing the literature, concluded that a daily dose of $250 \mu \mathrm{g}(10,000 \mathrm{IU})$ is considered to reflect a "no observed adverse effect level (NOAEL)" in adults because clinical studies evaluating such doses reported no vitamin D toxicity. Furthermore, this NOAEL seems to be biologically sound because the maximum endogenous vitamin D synthesis by natural sun (UV-B) exposure increases $25(\mathrm{OH}) \mathrm{D}$ levels equivalent to oral vitamin $\mathrm{D}$ intakes of about $500 \mu \mathrm{g}$ (20,000 IU) daily (92). In view of some uncertainties around this NOAEL an uncertainty factor of 2.5 was chosen leading to an UL of $100 \mu \mathrm{g}(4,000 \mathrm{IU})$ for adults. The concept of vitamin D safety also consists of the idea of adequate circulating 25(OH)D concentrations as well as those leading to toxicity. There is, however, uncertainty at which concentrations hypercalcemia occurs although it is frequently quoted that hypercalcemia usually only occurs at serum $25(\mathrm{OH}) \mathrm{D}$ concentrations above $375-500 \mathrm{nmol} / \mathrm{L}$. Importantly, the IOM has classified circulating $25(\mathrm{OH}) \mathrm{D}$ concentrations of $50-125 \mathrm{nmol} / \mathrm{L}$ as adequate and concentrations greater than $125 \mathrm{nmol} / \mathrm{L}$, if sustained, as potentially harmful, although this level is far lower than the serum $25(\mathrm{OH}) \mathrm{D}$ concentrations associated with hypercalcemia of approximately greater than $375-500 \mathrm{nmol} / \mathrm{L}$. The considerations regarding the term "potentially harmful" for serum 25(OH)D concentrations above $125 \mathrm{nmol} / \mathrm{L}$ until those concentrations leading to hypercalcemia is based on some observational studies indicating increased risk of adverse outcomes such as mortality at high $25(\mathrm{OH}) \mathrm{D}$ concentrations. It is important to underline that risk of adverse events at 25(OH)D concentrations above 125 $\mathrm{nmol} / \mathrm{L}$ has only been inconsistently reported in observational studies and the question of causality is still not answered. However, some RCTs seem to support the cautious approach of the IOM since daily vitamin D supplement doses of $100 \mu \mathrm{g}(4,000$ IU) or high bolus doses of vitamin D leading to serum 25(OH)D concentrations $>125 \mathrm{nmol} / \mathrm{L}$ might in specific population groups adversely impact musculo-skeletal and cardiovascular health $(77,78)$. On the other hand, several other studies using high doses of vitamin $\mathrm{D}$ or studying individuals with very high $25(\mathrm{OH}) \mathrm{D}$ concentrations did not report on adverse effects (77, $78,91)$. Nevertheless, considering these safety issues and some uncertainty regarding the long term effect of high 25(OH)D concentrations, integrated quantitative risk-benefit assessments according to proposed frameworks are warranted (93-96).

Although the risk of achieving potentially harmful circulating $25(\mathrm{OH}) \mathrm{D}$ concentrations by food fortification with vitamin D is likely to be small in the general population, the problem of idiopathic hypercalcemia should not be neglected. A biallelic mutation in the gene encoding for the vitamin D catabolizing enzyme 24-hydroxylase (CYP24A1) can cause infantile idiopathic 
TABLE 2 | Tolerable upper intake levels for vitamin D.

\begin{tabular}{lcc}
\hline $\begin{array}{l}\text { Country (health } \\
\text { authority) }\end{array}$ & USA and Canada (IOM) & Europe (EFSA) \\
\hline Age group & Vitamin $\mathbf{D}$ in $\boldsymbol{\mu}$ g per day $\mathbf{( 1} \boldsymbol{\mu} \mathbf{g}=\mathbf{4 0}$ international units) \\
\hline 0-6 months & 25 & 25 \\
$6-12$ months & 37.5 & 25 \\
$1-3$ years & 62.5 & 50 \\
$4-8$ years & 75 & 50 \\
$9-10$ years & 100 & 50 \\
$11-17$ years & 100 & 100 \\
18 years and older & 100 & 100 \\
Pregnancy & 100 & 100 \\
Lactation & 100 & 100 \\
\hline
\end{tabular}

IOM, Institute of Medicine; EFSA, European Food Safety Authority.

hypercalcemia $(97,98)$. This mutation results in vitamin D hypersensitivity and may have a prevalence of 1:33,000 births in Europe (98). The health consequences of this mutation in the adolescent and adult population are currently not known. When discussing the safety of vitamin D food fortification it must also be noted that improvement of vitamin $\mathrm{D}$ status by systematic food fortification may also likewise decrease the prevalence of persons taking vitamin $\mathrm{D}$ supplements exceeding the UL. In this context, it should also be noted that intermittent high dose vitamin $\mathrm{D}$ supplementation is quite common but may pose risk of adverse events. While daily vitamin $\mathrm{D}$ supplements with doses according to the RDA or equivalents are safe, intermittent high dose vitamin D supplementation may even increase the risk of fractures and falls (90). In this context, we believe that systematic vitamin $\mathrm{D}$ food fortification with subsequent improvement of vitamin $\mathrm{D}$ status in the general population may likewise decrease the potential public health burden (and costs) associated with overuse/overdosing of vitamin D supplements.

\section{HISTORY OF VITAMIN D FOOD FORTIFICATION}

Even before vitamin D was discovered, it had been observed that cod liver oil protects against rickets. Interestingly, it has been empirically shown that one teaspoon of cod liver oil, that contains approximately $10 \mu \mathrm{g}$ (400 IU) of vitamin D per day, is effective in preventing rickets (5). Successful treatment of rickets has also been demonstrated by sunlight or UV exposure of children in the 1920s followed by documentation that irradiation of food such as milk increased its anti-rachitic activity. Vitamin D food fortification has been widely introduced in the 1930s and 1940s in the United States and many other industrialized countries such Great Britain when it became possible to add purified vitamin D itself to food (92). In particular vitamin D fortified milk was produced at that time, but vitamin $\mathrm{D}$ has also been added to a variety of foods and beverages including amongst others beer, hot dogs and custard. This food fortification policy was extremely effective in preventing rickets but in the 1950s there was a change in public health policy as food fortification was banned in Great Britain and many other European countries because cases of hypercalcemia were observed that had been suspected to be attributable to vitamin $\mathrm{D}$ intoxication. Whether this was really the case is not clear. Beyond the combined effect of vitamin D overdosing due to different sources [heavy vitamin $\mathrm{D}$ enrichment of dried milk powder plus vitamin $\mathrm{D}$ fortified cereals plus daily supplement with 17.5-20 $\mu \mathrm{g}$ (700$800 \mathrm{IU})$ of vitamin D] it has also been hypothesized that the hypercalcemic children in Great Britain may have had an inherited disease called Williams syndrome. This syndrome is, apart from other pathologies, associated with hypercalcemia. Unfortunately, methods for measuring circulating $25(\mathrm{OH}) \mathrm{D}$ were not available at that time. Some symptoms of hypercalcemia had, however, been observed in infants in the former German Democratic Republic, where infants were supplemented with intermittent doses of $15 \mathrm{mg}(600,000 \mathrm{IU})$ of vitamin D as an effort to prevent rickets $(77,78)$. In these infants, serum $25(\mathrm{OH}) \mathrm{D}$ concentrations increased up to several hundred nmol/L.

\section{CURRENT VITAMIN D FOOD FORTIFICATION POLICIES}

Overviews of current food fortification policies have been reviewed elsewhere $(62,73,74,99-104)$. There is a huge variation in availability of vitamin $\mathrm{D}$ fortified food or food with vitamin $\mathrm{D}$ bioaddition across the countries. In general, there are mandatory and voluntary vitamin D food fortification policies but their differentiation is not always trivial as there can be varying pressure and implementation success of voluntary vitamin D food fortification. In Finland, for example, the Ministry of Trade and Industry recommended vitamin D fortification of fluid milks, margarines/fat spreads in 2003 on a voluntary, and not mandatory, basis, but most companies complied with the option to fortify resulting in a systematic (mass) vitamin $\mathrm{D}$ fortification (105-111). Many other countries allow voluntary vitamin $\mathrm{D}$ food fortification but with only insufficient effects on vitamin D intakes at population level $(104,112)$. Legislation is, of course, the basis for vitamin $\mathrm{D}$ food fortification and while we cannot discuss this issue in detail, we want to point out that the general regulation of voluntary food fortification is harmonized across the European Union (104, 113, 114). Several countries, however, still refer to national laws restricting addition of vitamins and minerals to food. In Germany, for example, addition of vitamin D to food is limited to margarine, based on a law of 1942.

As the experience with systematic (mass) vitamin D food fortification in the US, Canada and Finland may provide important guidance for health authorities in other regions, we list the main vitamin $\mathrm{D}$ fortified foods currently practiced in these countries in Table 3 (99, 100, 105-111, 115-117).

In particular, the example of Finland can serve as a benchmark for future vitamin $\mathrm{D}$ food fortification policies in other countries. In Finland, vitamin D status has recently been assessed in nationally representative samples before and after introduction of systematic vitamin D food fortification (105). These results 
TABLE 3 | Vitamin D food fortification in the United States, Canada and Finland.

\begin{tabular}{|c|c|c|c|}
\hline Food (serving) & United States & Canada & Finland \\
\hline \multicolumn{4}{|c|}{ VITAMIN D PER SERVING IN $\mu \mathrm{g}(1 \mu \mathrm{g}=40$ INTERNATIONAL UNITS) } \\
\hline & \multicolumn{3}{|c|}{ Mass fortification (usually mandatory) } \\
\hline Fluid cow's milk (250 ml or 1 cup) & $2.5-5.0^{\dagger}$ & $2.5-5.0^{\dagger \dagger}$ & 2.5 \\
\hline \multirow[t]{2}{*}{ Margarine/Fat spread (10 g) } & & $1.5-3.0^{\dagger \dagger}$ & 2.0 \\
\hline & \multicolumn{3}{|c|}{ Fortification of selected brands } \\
\hline Yogurt & $1.5-5.0$ per $170 \mathrm{~g}$ & 1.0 per $100 \mathrm{~g}$ & $0.5-1.0$ per $100 \mathrm{~g}$ \\
\hline Cheese slice (16 g) & 1.5 & & \\
\hline Orange juice (125 ml or $1 / 2$ cup) & 1.25 & 1.25 & 1.25 \\
\hline Plant-based milk such as soy, oat or almond (250 ml or 1 cup) & $1.5-3.0$ & $1.5-3.0$ & $1.9-3.75$ \\
\hline Margarine $10 \mathrm{~g}$ & $0.75-5.0$ & & \\
\hline Bread (100 g) & 2.25 & & 1.7 \\
\hline Cereals, ready-to-eat (1/2-3/4 cup) & $1-2.5$ & 1.0 & 3.0 per $100 \mathrm{~g}$ \\
\hline
\end{tabular}

${ }^{\dagger}$ FDA in 2016 permitted voluntary "doubling" of mandatory vitamin D in milk.

${ }^{+\dagger}$ Health Canada will require doubling of mandatory amounts by 2020.

are based on Vitamin D Standardization Program (VDSP)standardized 25(OH)D data (105), whereas older Finnish reports without VDSP data should only be interpreted with caution (106-110). In 2003, a systematic voluntary food fortification was introduced in Finland with the recommendation to add vitamin $\mathrm{D}$ at a dose of $10 \mu \mathrm{g} / 100 \mathrm{~g}$ to all fat spreads and at a dose of $0.5 \mu \mathrm{g} / 100 \mathrm{~g}$ to all fluid milk products. In 2010, these fortification recommendations were doubled to 20 $\mu \mathrm{g} / 100 \mathrm{~g}$ in all fat spreads and $1.0 \mu \mathrm{g} / 100 \mathrm{~g}$ in all fluid milk products. In a nationally representative survey of Finnish adults, changes in serum 25(OH)D concentrations from 2000 to 2011 were investigated (105). Mean serum $25(\mathrm{OH}) \mathrm{D}$ concentrations increased from $47.6 \mathrm{nmol} / \mathrm{L}$ in the year 2000 to $65.4 \mathrm{nmol} / \mathrm{L}$ in 2011. The prevalence of $25(\mathrm{OH}) \mathrm{D}$ concentrations below 30 , 40 , and $50 \mathrm{nmol} / \mathrm{L}$, respectively, was $13.0,32.0$, and $55.7 \%$ in 2000, and decreased to $0.6,3.2$, and 9.1\%, respectively, in 2011 . Importantly, serum $25(\mathrm{OH}) \mathrm{D}$ concentrations increased from 2000 to 2011 by about $34 \mathrm{nmol} / \mathrm{L}$ in individuals with $25(\mathrm{OH}) \mathrm{D}$ concentrations $<30 \mathrm{nmol} / \mathrm{L}$ in 2000 , whereas there was only an increase of about $11 \mathrm{nmol} / \mathrm{L}$ in individuals with $25(\mathrm{OH}) \mathrm{D}$ concentrations $\geq 50 \mathrm{nmol} / \mathrm{L}$ in 2000 . In 2011, only 8 out of 4051 individuals had serum $25(\mathrm{OH}) \mathrm{D}$ concentrations $\geq 125 \mathrm{nmol} / \mathrm{L}$ and of these 8 individuals, 7 were vitamin D supplement users. Although food fortification policy in Finland clearly improved vitamin $\mathrm{D}$ status over time, it must be mentioned that there was also an increase in vitamin D supplement use from $11 \%$ in 2000 to $41 \%$ in 2011. Furthermore, a part of the $25(\mathrm{OH}) \mathrm{D}$ increase (approximately $10 \mathrm{nmol} / \mathrm{L}$ increase) from 2000 to 2011 cannot be explained by vitamin $\mathrm{D}$ fortification and increased use of vitamin D supplements. It is also worth mentioning that fat spreads were already a substantial source of vitamin D intake in 2000 as they were recommended to be fortified by 5-10 $\mu \mathrm{g} / 100 \mathrm{~g}$ before systematic fortification started in 2003. Nevertheless, contribution to dietary vitamin D intake from fluid milk products, fat spreads, and fish changed from 4, 9, and 57\%, respectively, in 2000 to 34,10, and 38\%, respectively, in 2011 . When restricting the analyses to individuals with no supplement use, the mean overall increase in serum 25(OH)D from 2000 to 2011 was $6 \mathrm{nmol} / \mathrm{L}$ higher in individuals who consumed fluid milks products as compared to those who did not.

Therefore, and to conclude, the Finnish vitamin D nutrition policy, based on appropriate simulations, has considerably improved vitamin D status in the general Finnish population. This implementation of a systematic vitamin $\mathrm{D}$ food fortification programme respresents an example of a successful public health action that may inform similar approaches in other countries. Importantly, vitamin $\mathrm{D}$ food fortification policies have been re-evaluated and modified if necessary $(105,118)$. Apart from Western countries, there are also efforts for vitamin $\mathrm{D}$ food fortification in countries such as India (with e.g., vitamin D fortified milk), Jordan (with e.g., vitamin D fortified bread) and several others $(73,119-121)$.

\section{MODELING TO INFORM STRATEGIES FOR VITAMIN D FOOD FORTIFICATION}

Identifying the need for systematic vitamin $\mathrm{D}$ food fortification requires, of course, the assessment of $25(\mathrm{OH}) \mathrm{D}$ status and vitamin $\mathrm{D}$ intakes in a respective country or population in order to show that the dietary vitamin $\mathrm{D}$ requirements are not met. These data, which should at best be derived from a nationally representative sample of the population, can then serve as the basis for modeling vitamin $\mathrm{D}$ food fortification scenarios to meet the vitamin D requirements (122-135). A particular focus on groups at highest risk of profound vitamin D deficiency (e.g., those in high-risk ethnic groups or with restrictive diets) is also important.

Apart from the excellent "real-life" data from Finland on the effect of systematic vitamin D food fortification, there exist of course mathematical models to estimate different scenarios of vitamin $\mathrm{D}$ food fortification on vitamin $\mathrm{D}$ intakes and $25(\mathrm{OH}) \mathrm{D}$ status for a given population or country. In a very simplified view there are three different approaches for modeling effects of 
vitamin D food fortification scenarios. First, based on vitamin $\mathrm{D}$ intakes and nutrition habits in the population it can be estimated how vitamin $\mathrm{D}$ fortification affects nutritional vitamin $\mathrm{D}$ intakes by simply adding existing and additional vitamin D intakes by food fortification (112). Second, based on the previous approach and the availability of $25(\mathrm{OH}) \mathrm{D}$ concentrations and by use of a dose-response equation of vitamin $\mathrm{D}$ intake and $25(\mathrm{OH}) \mathrm{D}$ serum concentrations, it can be estimated how vitamin $\mathrm{D}$ fortification affects not only dietary vitamin $\mathrm{D}$ intakes but also serum 25(OH)D concentrations (127). Third, in addition to the second approach the additional impact of UV exposure with its seasonal variation is considered to model the effect of vitamin D food fortification on $25(\mathrm{OH}) \mathrm{D}$ serum concentrations $(125,126$, 128). All of these models have their limitations in particular due to some underlying assumptions so that cautious interpretation of the results is warranted. Regarding underlying assumptions it is important to note that when analyzing data from RCTs on vitamin $\mathrm{D}$ food fortification, it has been calculated that for every $1 \mu \mathrm{g}$ (40 IU) ingested vitamin $\mathrm{D}$, the serum 25(OH)D concentration increases by $1.2 \mathrm{nmol} / \mathrm{L}$ ( $95 \%$ confidence interval $0.72-1.68 \mathrm{nmol} / \mathrm{L})(123)$. Simple modeling of an equation on the vitamin $\mathrm{D}$ intake-serum $25(\mathrm{OH}) \mathrm{D}$ relationship does, however, not reflect potentially modifying factors such as body mass index, age, basal serum $25(\mathrm{OH}) \mathrm{D}$ concentrations or genetics (136).

\section{COST-EFFECTIVENESS OF VITAMIN D FOOD FORTIFICATION}

When considering introduction of systematic vitamin D food fortification, a key question relates to whether or not such a public health intervention is likely to be cost-effective (137151). In general, micronutrient fortification is considered as being one of the most cost-effective public health interventions (137). With reference to vitamin D food fortification there is, however, only limited evidence available on its cost-effectiveness. Nevertheless, the available studies on this issue point toward the notion that systematic vitamin $\mathrm{D}$ fortification (or vitamin $\mathrm{D}$ supplementation) may indeed be highly cost-effective (137-153). Regarding the costs for a typical food fortification programme, Fiedler et al. estimated the following distribution of costs: $80 \%$ recurrent production costs, $8 \%$ marketing and education costs, $7 \%$ food control and monitoring costs, and $5 \%$ other programmespecific recurrent production costs (137). Using these cost distributions and obtaining annual costs for $20 \mu \mathrm{g}$ (800 IU) vitamin $\mathrm{D}$ per day of 0.11 Euros per person and annual costs for $200 \mathrm{mg}$ calcium per day of 0.22 Euros per person it was estimated by Sandmann et al. that the implementation of a vitamin D plus calcium fortification programme in Germany would cost 41 million Euros per year while saving 365 million Euros per year as a result of reduced fracture costs (139). This would translate into a benefit-cost ratio of 9:1 which is even more conservative than other estimates of the cost-effectiveness of pure vitamin $\mathrm{D}$ interventions with even higher benefit-cost ratios $(138,140-149)$. We are well aware that more data are needed on the cost-effectiveness of systematic vitamin $\mathrm{D}$ fortification but we conclude that, despite limited evidence, the available literature suggests that this approach is highly likely to be costeffective. Despite these promising data, it must be stressed that the overall general health impact of systematic vitamin $\mathrm{D}$ food fortification or supplementation can only roughly be estimated (154-156). It should also be mentioned that most studies assessed the cost-effectiveness of vitamin $\mathrm{D}$ food fortification in the elderly population and not in the whole population. Beyond cost effectiveness it is, however of course, extremely important that such fortification approaches are also well perceived and accepted by the population itself. This seems to be the case for vitamin $\mathrm{D}$ as e.g., shown by a study in Germany (152). The Finnish data also suggest that vitamin D food fortification is well accepted and fortified foods are considered part of the habitual diet (105).

\section{SUGGESTIONS FOR VITAMIN D FOOD FORTIFICATION}

There is definitely no clear answer on how to implement systematic vitamin $\mathrm{D}$ food fortification in countries where the vitamin $\mathrm{D}$ dietary requirements are not met by a significant part of the general population. Nevertheless, we want to provide some guidance for this task (see Figure 2).

A first step is, of course, the evaluation of the vitamin D status and intakes from nationally representative nutrition and health surveys. Definition of a precise goal for vitamin D food fortification is not a trivial task, but the general aim is, of course, to improve vitamin $\mathrm{D}$ status while avoiding or minimizing risk of potential toxicity related to overdosing of vitamin $\mathrm{D}$. The Guidelines on food fortification with micronutrients by the World Health organization (WHO) define the goal of food fortification as follows: "to provide most (97.5\%) of individuals in the population group(s) at greatest risk of deficiency with an adequate intake of specific micronutrients, without causing a risk of excessive intakes in this or other groups" (153). The WHO guideline defines inadequate intakes as intakes below the EAR, which corresponds to a serum $25(\mathrm{OH}) \mathrm{D}$ concentration of $40 \mathrm{nmol} / \mathrm{L}$ according to the IOM report. Although not clearly outlined in the WHO guideline it appears reasonable to argue that intakes below this goal are a reason for public health actions. Being aware of the heterogeneity of nutritional vitamin $\mathrm{D}$ guidelines we are convinced that if significantly more than $2.5 \%$ of the population have $25(\mathrm{OH}) \mathrm{D}$ concentrations below $25-30 \mathrm{nmol} / \mathrm{L}$ there is a justified need for public health interventions including vitamin $\mathrm{D}$ food fortification, which becomes imperative if the prevalence increases close to or exceeds $20 \%$ in either the entire population or in populations subgroups.

Regarding the goal of vitamin D food fortification we are well aware that in the IOM report, the RDA for vitamin $\mathrm{D}$ intakes corresponds to $50 \mathrm{nmol} / \mathrm{L}$ of serum $25(\mathrm{OH}) \mathrm{D}$, and one may ask why we should not aim for this level in almost $(97.5 \%)$ the entire population. Bringing almost everyone to a level of at least $50 \mathrm{nmol} / \mathrm{L}$ of serum $25(\mathrm{OH}) \mathrm{D}$ is, however, considered unrealistic, costly, ineffective and (in particular) potentially risky because this means that the target median intake 


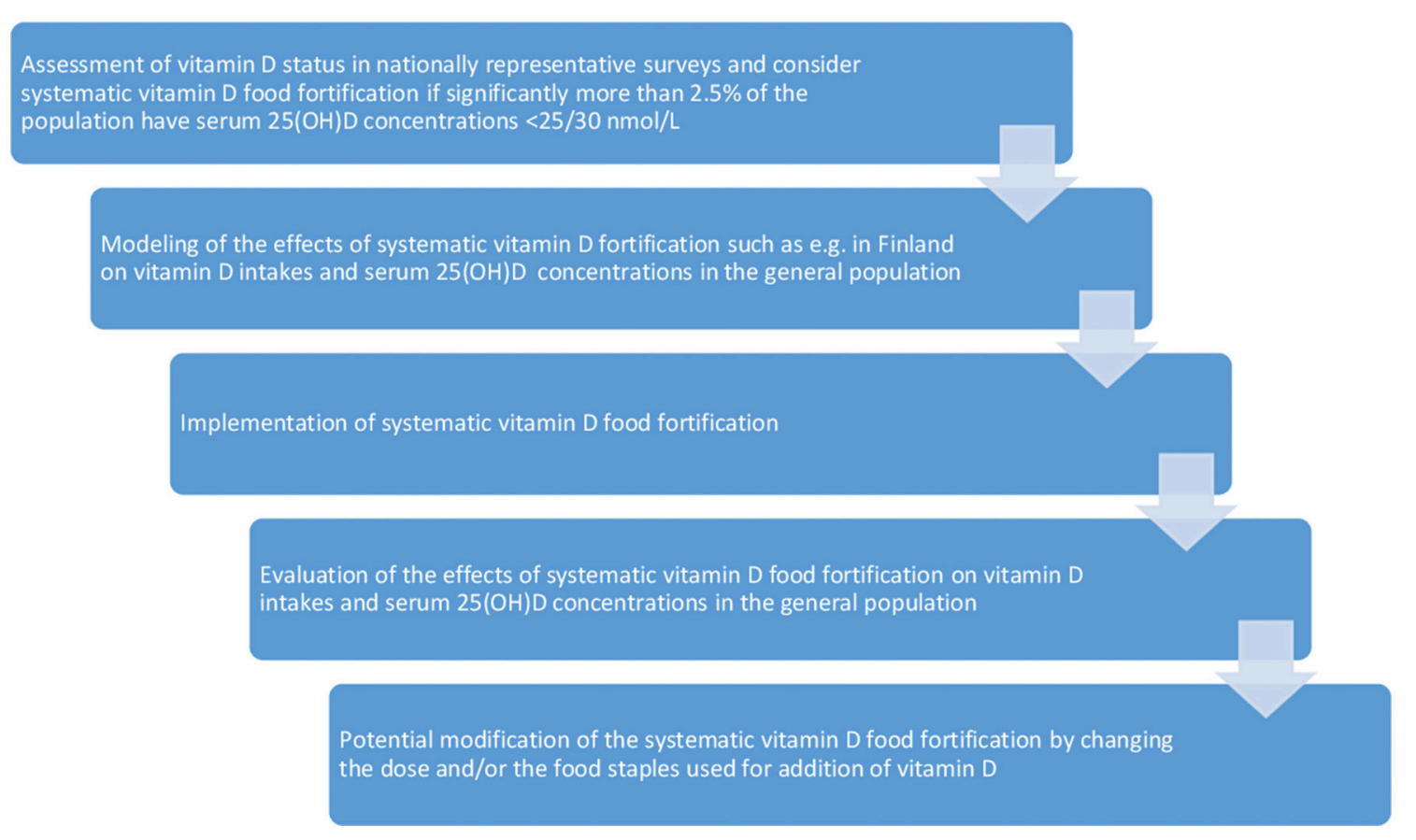

FIGURE 2 | Guidance for vitamin D food fortification.

would need to be set at very high levels $(153,157)$. It must be considered that even at vitamin $\mathrm{D}$ intakes between the EAR and the RDA and respective serum $25(\mathrm{OH}) \mathrm{D}$ concentrations of $40-50 \mathrm{nmol} / \mathrm{L}$, the majority of the individuals would meet their dietary vitamin $\mathrm{D}$ requirements. The $\mathrm{WHO}$ guideline on food fortification suggests the target is to shift the intake distribution upwards so that only $2.5 \%$ of the population have an intake below the EAR (154). Thus, nearly everyone in the population should have a daily vitamin $\mathrm{D}$ intake of at least about $10 \mu \mathrm{g}$ (400 IU) per day. This would, for a hypothetical usual intake distribution, result in a target median intake about 1.5 times above the RDA and approximately $20 \%$ of the population would have intakes below the RDA (153). This hypothetical example does, however, not fully apply for vitamin $\mathrm{D}$ because the distribution of $25(\mathrm{OH}) \mathrm{D}$ is different as shown in Finland where achieving a mean serum $25(\mathrm{OH}) \mathrm{D}$ concentration of $65 \mathrm{nmol} / \mathrm{L}$ by systematic vitamin $\mathrm{D}$ food fortification was sufficient to decrease the prevalence of $25(\mathrm{OH}) \mathrm{D}$ concentrations $<30 \mathrm{nmol} / \mathrm{L}$ in the general population below $1 \%$ (105). This provides extremely strong arguments for the safety of vitamin $\mathrm{D}$ because the Finish data indicate that with vitamin $\mathrm{D}$ food fortification there is a much higher increase in $25(\mathrm{OH}) \mathrm{D}$ in those with very low $25(\mathrm{OH}) \mathrm{D}$ concentrations at baseline when compared to those with high $25(\mathrm{OH}) \mathrm{D}$ concentrations at baseline.

In general, we see two broad approaches to implementation of systematic vitamin D food fortification. The first one adheres to previous systematic vitamin D food fortifications in countries with similar population characteristics in terms of vitamin D status and food habits that have been evaluated with regard to safety and efficacy, as it has been done in Finland. It is a reasonable approach to follow the example of the Finnish vitamin $\mathrm{D}$ food fortification policy when modeling of the effects of such a vitamin $\mathrm{D}$ food fortification results in a significant and safe improvement of vitamin D status and intakes. The second approach is based on an "optimal modeling" of systematic vitamin $\mathrm{D}$ food fortification of many different food products to increase vitamin D status. It is clear from hypothetical models of vitamin $\mathrm{D}$ intakes and status that fortifying multiple food staples is desirable because such approaches reach broader parts of the population and are theoretically more safe than just fortifying one or a few food staples. However, such approaches are more costly and will likewise have a lower acceptance as there are currently no countries using and evaluating such approaches.

As some of the authors reside in Austria and Germany we wish to briefly outline the conceivable food fortification scenarios in these two countries (158-168). Data from national representative samples on vitamin D status and intakes in Austria and Germany are shown in Table 4. It is obvious from the high prevalence of low $25(\mathrm{OH}) \mathrm{D}$ concentrations and the low dietary vitamin $\mathrm{D}$ intakes that vitamin $\mathrm{D}$ food fortification is necessary in these countries to meet the vitamin $\mathrm{D}$ requirements. In this context, we wish to underline that there is long experience with vitamin $\mathrm{D}$ food fortification of dairy products in different countries covering a wide range of different nutritional habits, lifestyle and latitudes. Therefore, we are of the opinion that systematic vitamin D fortification of milk and margarine/fat spreads (dairy products) according to the approach used in Finland would be a reasonable approach also in Austria and 
TABLE 4 | Vitamin D intakes and status in Austria and Germany.

\begin{tabular}{|c|c|c|c|c|c|c|c|c|c|}
\hline \multirow[t]{3}{*}{ Group } & \multicolumn{2}{|c|}{ Intakes in $\mu \mathrm{g}$ per day } & \multicolumn{7}{|c|}{$\begin{array}{l}\text { Serum/plasma } 25 \text {-hydroxyvitamin } \mathrm{D} \text { in } \mathrm{nmol} / \mathrm{L} \text { or percentages below } \\
\text { a } 25 \text {-hydroxyvitamin } \mathrm{D} \text { cut-off concentration }\end{array}$} \\
\hline & \multirow[t]{2}{*}{$\begin{array}{l}\text { Mean } \\
\text { (SD) }\end{array}$} & \multirow[t]{2}{*}{$\begin{array}{l}\text { Median (25th to75th } \\
\text { percentile or IQR) }\end{array}$} & Mean (SD) & $\begin{array}{l}\text { Median (25th to75th } \\
\text { percentile or IQR) }\end{array}$ & $<25$ & $<30$ & $<40$ & $<50$ & $<75$ \\
\hline & & & \multicolumn{2}{|r|}{$\mathrm{nmol} / \mathrm{L}$} & \multicolumn{5}{|c|}{ Percentages } \\
\hline \multicolumn{10}{|l|}{ AUSTRIA } \\
\hline \multicolumn{10}{|c|}{ Austrian Study on Nutritional Status 2017} \\
\hline Female adults & $2.3(2.4)$ & $1.7(1.1-2.8)$ & & & & & & & \\
\hline Male adults & $2.7(2.6)$ & $2.0(1.2-3.4)$ & & & & & & & \\
\hline \multicolumn{10}{|c|}{ Austrian Study on Nutritional Status 2012} \\
\hline Girls $7-14$ years & & $1.26(1.00)$ & & $44.9(32.5)$ & 22.3 & & & 62.3 & \\
\hline Boys $7-14$ years & & $1.39(0.93)$ & & $44.7(36.0)$ & 17.7 & & & 55.8 & \\
\hline Women 18-64 years & & $2.6(2.2-3.1)$ & & $57.4(47.5)$ & 11.6 & & & 39.8 & \\
\hline Women $65-80$ years & & $3.2(2.5-3.8)$ & & $42.3(28.5)$ & 19.9 & & & 42.4 & \\
\hline Men 18-64 years & & $3.9(3.1-4.7)$ & & $55.9(51.2)$ & 14.2 & & & 43.9 & \\
\hline Men 65-80 years & & $3.9(2.9-5.0)$ & & $41.8(28.4)$ & 20.4 & & & 44.4 & \\
\hline \multicolumn{10}{|l|}{ GERMANY } \\
\hline \multicolumn{10}{|c|}{ German Health Interview and Examination Survey for Children (KiGGS; 2003 until 2006) } \\
\hline All children & & & $54.0(19.2)$ & $52.9(39.4-71.6)$ & 6.0 & 12.5 & 25.9 & 45.6 & 83.8 \\
\hline Girls 6-11 years & & $1.3(0.8-2.1)$ & & & & & & & \\
\hline Girls $12-17$ years & & $1.7(1.2-2.5)$ & & & & & & & \\
\hline Boys $6-11$ years & & $1.4(0.9-2.1)$ & & & & & & & \\
\hline Boys $12-17$ years & & $2.2(1.5-3.3)$ & & & & & & & \\
\hline \multicolumn{10}{|c|}{ German Health Interview and Examination Survey for Adults (DEGS1; 2008 until 2011) } \\
\hline All adults & & & $50.1(18.1)$ & $47.7(36.1-60.8)$ & 4.2 & 15.2 & 34.3 & 56.0 & 90.9 \\
\hline \multicolumn{10}{|c|}{ German National Health Interview and Examination Survey (GNHIES; 1997 until 1999) } \\
\hline Women & & $2.31(1.53-3.56)$ & & & & & & & \\
\hline Men & & $2.81(1.89-4.44)$ & & & & & & & \\
\hline
\end{tabular}

Germany. Modeling of such a vitamin D fortification scenario on vitamin $\mathrm{D}$ intakes and on serum $25(\mathrm{OH}) \mathrm{D}$ concentrations is, of course, definitely required. Importantly, in Austria and Germany there is a similar yet slightly lower dairy intake but slightly higher $25(\mathrm{OH}) \mathrm{D}$ concentrations compared to Finland before the introduction of systematic vitamin D food fortification, suggesting that the Finnish approach may be a good model for these two countries (169). High prevalences of vitamin D deficiency with a need for improvement of vitamin D status are, however, also observed in many other European countries such as Poland with $16 \%$ of the general population having serum 25(OH)D concentrations below $25 \mathrm{nmol} / \mathrm{L}$ (170, 171).

In general, following the examples of other countries with vitamin $\mathrm{D}$ fortification of milk and margarines/fat spreads may likewise facilitate the implementation and the acceptance of mass fortification in the population. Additionally or alternatively, fortification of other foods such as bread may be considered in particular if dietary vitamin $\mathrm{D}$ requirements cannot be adequately met with vitamin D fortification of milk and margarine/fat spreads. Standardized measurements of $25(\mathrm{OH}) \mathrm{D}$ status and assessment of overall vitamin $\mathrm{D}$ intakes in nationally representative samples before and after implementation of vitamin $\mathrm{D}$ food fortification should be, of course, a condition
TABLE 5 | Key points.

*Health authorities recommend target serum 25(OH)D concentrations ranging from $\geq 25$ to $\geq 50 \mathrm{nmol} / \mathrm{L}(\geq 10$ to $\geq 20 \mathrm{ng} / \mathrm{mL}$ ),

corresponding to a daily vitamin D intake of 10-20 $\mu \mathrm{g}$ (400-800 IU)

*Most populations fail to meet these recommended dietary vitamin $\mathrm{D}$ requirements

*Systematic vitamin D food fortification is an effective and safe approach to improve vitamin D status in the general population

*Some countries such as the US, Canada, India and Finland have already introduced systematic vitamin D food fortification

*Introduction and/or modification of systematic vitamin D food fortification is required in many countries to improve public health, and should be based on modeling scenarios and efficacy data of vitamin $D$ food fortification from other countries such as Finland

sine qua non. While we hope for and work on the improvement of food fortification approaches in the future, it is now time to take action and work on the improvement of vitamin $\mathrm{D}$ status in countries where significant parts of the population fail to meet the dietary requirements. For this aim, the best evaluated vitamin $\mathrm{D}$ food fortification strategies with the likewise highest rates of successful implementation should be pursued. 


\section{CONCLUSIONS}

In this review, we outlined the background, rationale and current status of systematic vitamin D food fortification and also gave some guidance for implementation of such an approach (see Table 5 for key points). We are of the opinion that the huge gap between the nutritional vitamin $\mathrm{D}$ guideline recommendations and the high prevalence of individuals who do not meet their vitamin $\mathrm{D}$ requirements calls for public health actions that can be performed by systematic vitamin $\mathrm{D}$ food fortification. While there are still many questions surrounding this issue, several countries do have long experience with systematic vitamin D food fortification (172-176). The successful and well evaluated

\section{REFERENCES}

1. Pilz S, Gaksch M, Hartaigh BÓ, Tomaschitz A, März W. Vitamin $\mathrm{D}$ in preventive medicine. Anticancer Res. (2015) 35:1161-70. doi: 10.1079/BJN2003837

2. Fiscaletti M, Stewart P, Munns CF. The importance of vitamin D in maternal and child health: a global perspective. Public Health Rev. (2017) 38:19. doi: 10.1186/s40985-017-0066-3

3. Holick MF. The vitamin D deficiency pandemic: approaches for diagnosis, treatment and prevention. Rev Endocr Metab Disord. (2017) 18:153-65. doi: 10.1007/s11154-017-9424-1

4. Hayes A, Cashman KD. Food-based solutions for vitamin D deficiency: putting policy into practice and the key role for research. Proc Nutr Soc. (2017) 76:54-63. doi: 10.1017/S0029665116000756

5. Bouillon R. Comparative analysis of nutritional guidelines for vitamin D. Nat Rev Endocrinol. (2017) 13:466-79. doi: 10.1038/nrendo.2017.31

6. Pilz S, Trummer C, Pandis M, Schwetz V, Aberer F, Grübler M, et al. Vitamin D: current guidelines and future outlook. Anticancer Res. (2018) 38:1145-51. doi: 10.21873 /anticanres.12333

7. Cashman KD. Vitamin D: dietary requirements and food fortification as a means of helping achieve adequate vitamin D status. J Steroid Biochem Mol Biol. (2015) 148:19-26. doi: 10.1016/j.jsbmb.2015.01.023

8. Itkonen ST, Lamberg-Allardt C. Food fortification as a means to increase vitamin D intake. Br J Nutr. (2016) 115:2075-6. doi: 10.1017/S0007114516001227

9. Christakos S, Dhawan P, Verstuyf A, Verlinden L, Carmeliet G. Vitamin D: metabolism, molecular mechanism of action, and pleiotropic effects. Physiol Rev. (2016) 96:365-408. doi: 10.1152/physrev.00014.2015

10. Rooney MR, Harnack L, Michos ED, Ogilvie RP, Sempos CT, Lutsey PL. Trends in use of high-dose Vitamin D supplements exceeding 1000 or 4000 International units daily, 1999-2014. JAMA (2017) 317:2448-50. doi: 10.1001/jama.2017.4392

11. Martinaityte I, Kamycheva E, Didriksen A, Jakobsen J, Jorde R. Vitamin $\mathrm{D}$ stored in fat tissue during a 5-year intervention affects serum 25hydroxyvitamin D Levels the following year. J Clin Endocrinol Metab. (2017) 102:3731-8. doi: 10.1210/jc.2017-01187

12. Macdonald HM, Mavroeidi A, Fraser WD, Darling AL, Black AJ, Aucott L, et al. Sunlight and dietary contributions to the seasonal vitamin D status of cohorts of healthy postmenopausal women living at northerly latitudes: a major cause for concern? Osteoporos Int. (2011) 22:2461-72. doi: 10.1007/s00198-010-1467-z

13. Jiang X, O’Reilly PF, Aschard H, Hsu YH, Richards JB, Dupuis J, et al. Genome-wide association study in 79,366 European-ancestry individuals informs the genetic architecture of 25-hydroxyvitamin D levels. Nat Commun. (2018) 9:260. doi: 10.1038/s41467-017-02 $662-2$

14. Bouillon R. Genetic and Racial Differences in the Vitamin D endocrine system. Endocrinol Metab Clin North Am. (2017) 46:1119-35. doi: 10.1016/j.ecl.2017.07.014 real-life experience with the Finnish food fortification policy may be used as a benchmark for other countries with similar population characteristics. We do hope that our work helps to introduce and modify vitamin $\mathrm{D}$ food fortification in those countries where it is needed in order to prevent the significant public health burden of vitamin D deficiency and its adverse consequences.

\section{AUTHOR CONTRIBUTIONS}

SP, WM, and AZ drafted an initial version of the manuscript. All authors contributed to manuscript revision, read and approved the submitted version.

15. Bikle DD, Malmstroem S, Schwartz J. Current Controversies: are free vitamin metabolite levels a more accurate assessment of Vitamin D status than total levels? Endocrinol Metab Clin North Am. (2017) 46:901-18. doi: 10.1016/j.ecl.2017.07.013

16. Pilz S, Obeid R, Schwetz V, Trummer C, Pandis M, Lerchbaum E, et al. Hormonal contraceptive use is associated with higher total but unaltered free 25-hydroxyvitamin D serum concentrations. J Clin Endocrinol Metab. (2018) 103:2385-91. doi: 10.1210/jc.2018-00336

17. Jorde R, Grimnes G. Serum cholecalciferol may be a better marker of vitamin D status than 25-hydroxyvitamin D. Med Hypotheses (2018) 111:61-5. doi: 10.1016/j.mehy.2017.12.017

18. Carpenter TO, Shaw NJ, Portale AA, Ward LM, Abrams SA, Pettifor JM. Rickets. Nat Rev Dis Primers (2017) 3:17101. doi: 10.1038/nrdp.2017.101

19. Uday S, Högler W. Nutritional rickets and Osteomalacia in the Twentyfirst Century: revised concepts, public health, and prevention strategies. Curr Osteoporos Rep. (2017) 15:293-302. doi: 10.1007/s11914-017-0383-y

20. Munns CF, Shaw N, Kiely M, Specker BL, Thacher TD, Ozono K, et al. Global consensus recommendations on prevention and management of nutritional rickets. J Clin Endocrinol Metab. (2016) 101:394-415. doi: $10.1210 /$ jc. $2015-2175$

21. Bischoff-Ferrari HA, Willett WC, Orav EJ, Lips P, Meunier PJ, Lyons RA, et al. A pooled analysis of vitamin $\mathrm{D}$ dose requirements for fracture prevention. $N$ Engl J Med. (2012) 367:40-9. doi: 10.1056/NEJMoa1109617

22. Weaver CM, Alexander DD, Boushey CJ, Dawson-Hughes B, Lappe JM, LeBoff MS, et al. Calcium plus vitamin D supplementation and risk of fractures: an updated meta-analysis from the National Osteoporosis Foundation. Osteoporos Int. (2016) 27:367-76. doi: 10.1007/s00198-015-3386-5

23. Bolland MJ, Grey A, Reid IR. Differences in overlapping meta-analyses of vitamin D supplements and falls. J Clin Endocrinol Metab. (2014) 99:426572. doi: 10.1210/jc.2014-2562

24. Zhao JG, Zeng XT, Wang J, Liu L. Association between calcium or vitamin D supplementation and fracture incidence in community-dwelling older adults: a systematic review and meta-analysis. JAMA (2017) 318:2466-82. doi: 10.1001/jama.2017.19344

25. Avenell A, Mak JC, O'Connell D. Vitamin D and vitamin D analogues for preventing fractures in post-menopausal women and older men. Cochrane Database Syst Rev. (2014) 4:CD000227. doi: 10.1002/14651858.CD000227

26. US Preventive Services Task Force, Grossman DC, Curry SJ, Owens DK, Barry MJ, Caughey AB, et al. Vitamin D, calcium, or combined supplementation for the primary prevention of fractures in communitydwelling adults: US preventive services task force recommendation statement. JAMA (2018) 319:1592-99. doi: 10.1001/jama.2018.3185

27. Bischoff-Ferrari HA, Bhasin S, Manson JE. Preventing fractures and falls: a limited role for calcium and vitamin D supplements? JAMA (2018) 319:1552-3. doi: 10.1001/jama.2018.4023

28. Gaksch M, Jorde R, Grimnes G, Joakimsen R, Schirmer H, Wilsgaard $\mathrm{T}$, et al. Vitamin $\mathrm{D}$ and mortality: individual participant data metaanalysis of standardized 25-hydroxyvitamin D in 26916 individuals 
from a European consortium. PLoS ONE (2017) 12:e0170791. doi: 10.1371/journal.pone.0170791

29. Pilz S, Verheyen N, Grübler MR, Tomaschitz A, März W. Vitamin D and cardiovascular disease prevention. Nat Rev Cardiol. (2016) 13:404-17. doi: 10.1038/nrcardio.2016.73

30. Muscogiuri G, Altieri B, Annweiler C, Balercia G, Pal HB, Boucher BJ, et al. Vitamin D and chronic diseases: the current state of the art. Arch Toxicol. (2017) 91:97-107. doi: 10.1007/s00204-016-1804-x

31. Pludowski P, Holick MF, Pilz S, Wagner CL, Hollis BW, Grant WB, et al. Vitamin D effects on musculoskeletal health, immunity, autoimmunity, cardiovascular disease, cancer, fertility, pregnancy, dementia and mortality-a review of recent evidence. Autoimmun Rev. (2013) 12:97689. doi: $10.1016 /$ j.autrev.2013.02.004

32. Autier P, Mullie P, Macacu A, Dragomir M, Boniol M, Coppens K, et al. Effect of vitamin D supplementation on non-skeletal disorders: a systematic review of meta-analyses and randomised trials. Lancet Diabetes Endocrinol. (2017) 5:986-1004. doi: 10.1016/S2213-8587(17)30357-1

33. Rejnmark L, Bislev LS, Cashman KD, Eiríksdottir G, Gaksch M, Grübler M, et al. Non-skeletal health effects of vitamin D supplementation: a systematic review on findings from meta-analyses summarizing trial data. PLOS ONE (2017) 12:e0180512. doi: 10.1371/journal.pone.0180512

34. Bjelakovic G, Gluud LL, Nikolova D, Whitfield K, Wetterslev J, Simonetti RG, et al. Vitamin D supplementation for prevention of mortality in adults. Cochrane Database Syst Rev. (2014) 6:CD007470. doi: 10.1002/14651858.CD007470

35. Chowdhury R, Kunutsor S, Vitezova A, Oliver-Williams C, Chowdhury S, Kiefte-de-Jong JC, et al. Vitamin D and risk of cause specific death: systematic review and meta-analysis of observational cohort and randomised intervention studies. BMJ (2014) 348:g1903. doi: 10.1136/bmj.g1903

36. Martineau AR, Jolliffe DA, Hooper RL, Greenberg L, Aloia JF, Bergman $\mathrm{P}$, et al. Vitamin D supplementation to prevent acute respiratory tract infections: systematic review and meta-analysis of individual participant data. $B M J$ (2017) 356:i6583. doi: 10.1136/bmj.i6583

37. Zittermann A, Pilz S, Hoffmann H, März W. Vitamin D and airway infections: a European perspective. Eur J Med Res. (2016) 21:14. doi: 10.1186/s40001-016-0208-y

38. De-Regil LM, Palacios C, Lombardo LK, Peña-Rosas JP. Vitamin D supplementation for women during pregnancy. Cochrane Database Syst Rev. (2016) 15:CD008873. doi: 10.1002/14651858.CD008873

39. Roth DE, Leung M, Mesfin E, Qamar H, Watterworth J, Papp E. Vitamin D supplementation during pregnancy: state of the evidence from a systematic review of randomised trials. BMJ (2017) 359:j5237. doi: 10.1136/bmj. j5237

40. Martineau AR, Cates CJ, Urashima M, Jensen M, Griffiths AP, Nurmatov U, et al. Vitamin D for the management of asthma. Cochrane Database Syst Rev. (2016) 9:CD011511. doi: 10.1002/14651858.CD011511

41. Jolliffe DA, Greenberg L, Hooper RL, Griffiths CJ, Camargo CA Jr, Kerley $\mathrm{CP}$, et al. Vitamin D supplementation to prevent asthma exacerbations: a systematic review and meta-analysis of individual participant data. Lancet Respir Med. (2017) 5:881-890. doi: 10.1016/S2213-2600(17)30306-5

42. Rostami M, Tehrani FR, Simbar M, Yarandi RB, Minooee S, Hollis BW, et al. Effectiveness of prenatal vitamin D deficiency screening and treatment program: a stratified randomized field trial. J Clin Endocrinol Metab. (2018). doi: 10.1210/jc.2018-00109. [Epub ahead of print].

43. Wolsk HM, Chawes BL, Litonjua AA, Hollis BW, Waage J, Stokholm J, et al. Prenatal vitamin D supplementation reduces risk of asthma/recurrent wheeze in early childhood: a combined analysis of two randomized controlled trials. PLoS ONE (2017) 12:e0186657. doi: 10.1371/journal.pone.0186657

44. Sollid ST, Hutchinson MY, Fuskevåg OM, Joakimsen RM, Jorde R. Large individual differences in serum 25-Hydroxyvitamin D response To Vitamin D supplementation: effects of genetic factors, body mass index, and baseline concentration. results from a randomized controlled trial. Horm Metab Res. (2016) 48:27-34. doi: 10.1055/s-0034-1398617

45. Ross AC, Manson JE, Abrams SA, Aloia JF, Brannon PM, Clinton SK, et al. The 2011 report on dietary reference intakes for calcium and vitamin D from the Institute of Medicine: what clinicians need to know. J Clin Endocrinol Metab. (2011) 96:53-8. doi: 10.1210/jc.2010-2704
46. Institute of Medicine (US). Committee to Review Dietary Reference Intakes for Vitamin D and Calcium. In: Ross AC, Taylor CL, Yaktine AL, Del Valle HB, editors. Dietary Reference Intakes for Calcium and Vitamin D. Washington, DC: National Academies Press (US) (2011).

47. EFSA NDA Panel (EFSA Panel on Dietetic Products, Nutrition and Allergies), 2016. Scientific opinion on dietary reference values for vitamin D. EFSA J. (2016) 14:4547. doi: 10.2903/j.efsa.2016.4547

48. Available online at: https://www.gov.uk/government/groups/scientificadvisory-committee-on-nutrition

49. German Nutrition Society. New reference values for vitamin D. Ann Nutr Metab. (2012) 60:241-6. doi: 10.1159/000337547

50. Nordic Council of Ministers, 2014. Nordic Nutrition Recommendation 2012. Integrating Nutrition and Physical Activity. Copenhagen: Nordic Council of Ministers.

51. Holick MF, Binkley NC, Bischoff-Ferrari HA, Gordon CM, Hanley DA, Heaney RP, et al. Evaluation, treatment, and prevention of vitamin D deficiency: an Endocrine Society clinical practice guideline. J Clin Endocrinol Metab. (2011) 96:1911-30. doi: 10.1210/jc.2011-0385

52. Brouwer-Brolsma EM, Bischoff-Ferrari HA, Bouillon R, Feskens EJ, Gallagher CJ, Hypponen E, et al. Vitamin D: do we get enough? A discussion between vitamin $\mathrm{D}$ experts in order to make a step towards the harmonisation of dietary reference intakes for vitamin D across Europe. Osteoporos Int. (2013) 24:1567-77. doi: 10.1007/s00198-012-2231-3

53. Pludowski P, Holick MF, Grant WB, Konstantynowicz J, Mascarenhas MR, Haq A, et al. Vitamin D supplementation guidelines. J Steroid Biochem Mol Biol. (2018) 175:125-35. doi: 10.1016/j.jsbmb.2017.01.021

54. van Schoor N, Lips P. Global overview of vitamin d Status. Endocrinol Metab Clin North Am. (2017) 46:845-70. doi: 10.1016/j.ecl.2017.07.002

55. Cashman KD, Dowling KG, Škrabáková Z, Gonzalez-Gross M, Valtueña J, De Henauw S, et al. Vitamin D deficiency in Europe: pandemic? Am J Clin Nutr. (2016) 103:1033-44. doi: 10.3945/ajcn.115.120873

56. Cashman KD, Sheehy T, O'Neill CM. Is vitamin D deficiency a public health concern for low middle income countries? A systematic literature review. Eur J Nutr. doi: 10.1007/s00394-018-1607-3. [Epub ahead of print].

57. Schleicher RL, Sternberg MR, Lacher DA, Sempos CT, Looker AC, DurazoArvizu RA, et al. The vitamin D status of the US population from 1988 to 2010 using standardized serum concentrations of 25-hydroxyvitamin D shows recent modest increases. Am J Clin Nutr. (2016) 104:454-61. doi: 10.3945/ajcn.115.127985

58. Schleicher RL, Sternberg MR, Looker AC, Yetley EA, Lacher DA, Sempos $\mathrm{CT}$, et al. National estimates of serum total 25-Hydroxyvitamin D and metabolite concentrations measured by liquid chromatography-tandem mass spectrometry in the us population during 2007-2010. J Nutr. (2016) 146:1051-61. doi: 10.3945/jn.115.227728

59. Manios Y, Moschonis G, Lambrinou CP, Tsoutsoulopoulou K, Binou P, Karachaliou A, et al. A systematic review of vitamin D status in southern European countries. Eur J Nutr. doi: 10.1007/s00394-017-1564-2. [Epub ahead of print].

60. Spiro A, Buttriss JL. Vitamin D: an overview of vitamin D status and intake in Europe. Nutr Bull. (2014) 39:322-50. doi: 10.1111/nbu.12108

61. Calvo MS, Whiting SJ, Barton CN. Vitamin D intake: a global perspective of current status. J Nutr. (2005) 135:310-6. doi: 10.1093/jn/135.2.310

62. Kiely M, Black LJ. Dietary strategies to maintain adequacy of circulating 25-hydroxyvitamin $\mathrm{D}$ concentrations. Scand J Clin Lab Invest Suppl. (2012) 243:14-23. doi: 10.3109/00365513.2012. 681893

63. Wahl DA, Cooper C, Ebeling PR, Eggersdorfer M, Hilger J, Hoffmann K, et al. A global representation of vitamin D status in healthy populations. Arch Osteoporos (2012) 7:155-72. doi: 10.1007/s11657-012-0093-0

64. Cashman KD, Kiely M. Recommended dietary intakes for vitamin D: where do they come from, what do they achieve and how can we meet them? J Hum Nutr Diet (2014) 27:434-42. doi: 10.1111/jhn.12226

65. Abrahamsen B. Bespoke or one size fits all-Vitamin D fortification, targeted supplementation in risk groups or individual measurement? Maturitas (2017) 103:1-2. doi: 10.1016/j.maturitas.2017.06.001

66. Jager N, Schöpe J, Wagenpfeil S, Bocionek P, Saternus R, Vogt T, et al. The impact of UV-dose, body surface area exposed and other factors on cutaneous vitamin D synthesis measured as serum $25(\mathrm{OH}) \mathrm{D}$ concentration: 
systematic review and meta-analysis. Anticancer Res. (2018) 38:1165-71. doi: 10.21873/anticanres.12336

67. O’Neill CM, Kazantzidis A, Ryan MJ, Barber N, Sempos CT, Durazo-Arvizu RA, et al. Seasonal changes in vitamin D-effective UVB availability in Europe and Associations with population serum 25-Hydroxyvitamin D. Nutrients (2016) 8:E533. doi: 10.3390/nu8090533

68. Webb AR, Engelsen O. Ultraviolet exposure scenarios: risks of erythema from recommendations on cutaneous vitamin D synthesis. Adv Exp Med Biol. (2014) 810:406-22. doi: 10.1007/978-1-4939-0437-2_23

69. Grigalavicius M, Moan J, Dahlback A, Juzeniene A. Daily, seasonal, and latitudinal variations in solar ultraviolet $\mathrm{A}$ and $\mathrm{B}$ radiation in relation to vitamin D production and risk for skin cancer. Int J Dermatol. (2016) 55:e23-8. doi: 10.1111/ijd.13065

70. Seckmeyer G, Schrempf M, Wieczorek A, Riechelmann S, Graw K, Seckmeyer S, et al. A novel method to calculate solar UV exposure relevant to vitamin D production in humans. Photochem Photobiol. (2013) 89:974-83. doi: $10.1111 /$ php. 12074

71. Vimaleswaran KS, Berry DJ, Lu C, Tikkanen E, Pilz S, Hiraki LT, et al. Causal relationship between obesity and vitamin D status: bi-directional Mendelian randomization analysis of multiple cohorts. PLoS Med. (2013) 10:e1001383. doi: 10.1371/journal.pmed.1001383

72. Himbert C, Ose J, Delphan M, Ulrich CM. A systematic review of the interrelation between diet- and surgery-induced weight loss and vitamin D status. Nutr Res. (2017) 38:13-26. doi: 10.1016/j.nutres.2016. 12.004

73. Whiting SJ, Calvo MS. Vitamin D fortification and supplementation policies to correct vitamin D insuficiency globally. In: Feldman D, Pike WS, Bouillon R, Giovannucci E, Goltzman D, Hewison M, editors. Vitamin D, Volume 2: Health, Disease and Therapeutics. 4th ed. London: Academic Press (2018). p. 91-108.

74. Cashman KD, Kiely M. Vitamin D and food fortification. In: Feldman D, Pike WS, Bouillon R, Giovannucci E, Goltzman D, Hewison M, editors. Vitamin D, Volume 2: Health, Disease and Therapeutics. 4th ed. London: Academic Press (2018). p. 109-27.

75. Lehmann U, Gjessing HR, Hirche F, Mueller-Belecke A, Gudbrandsen OA, Ueland PM, et al. Efficacy of fish intake on vitamin D status: a metaanalysis of randomized controlled trials. Am J Clin Nutr. (2015) 102:837-47. doi: 10.3945/ajcn.114.105395

76. Rundblad A, Holven KB, Bruheim I, Myhrstad MC, Ulven SM. Effects of krill oil and lean and fatty fish on cardiovascular risk markers: a randomised controlled trial. J Nutr Sci. (2018) 7:e3. doi: 10.1017/jns.2017.64

77. Zittermann A. The Biphasic effect of vitamin D on the musculoskeletal and cardiovascular system. Int J Endocrinol. (2017) 2017:3206240. doi: $10.1155 / 2017 / 3206240$

78. Zittermann A, Prokop S, Gummert JF, Börgermann J. Safety issues of vitamin D supplementation. Anticancer Agents Med Chem. (2013) 13:4-10. doi: 10.2174/1871520611307010004

79. Eureopan Food Safety Authority. Scientific opinion on the tolerable upper intake level of vitamin D. EFSA J. (2012) 10:2813. doi: 10.2903/j.efsa.2012.2813

80. Gallo S, Comeau K, Vanstone C, Agellon S, Sharma A, Jones G, et al. Effect of different dosages of oral vitamin $\mathrm{D}$ supplementation on vitamin $\mathrm{D}$ status in healthy, breastfed infants: a randomized trial. JAMA (2013) 309:1785-92. doi: 10.1001/jama.2013.3404

81. Vieth R. Vitamin D toxicity, policy, and science. J Bone Miner Res. (2007) 22 Suppl 2:V64-8 doi: 10.1359/jbmr.07s221

82. Maalouf J, Nabulsi M, Vieth R, Kimball S, El-Rassi R, Mahfoud Z, et al. Short- and long-term safety of weekly high-dose vitamin D3 supplementation in school children. J Clin Endocrinol Metab. (2008) 93:2693-701. doi: 10.1210/jc.2007-2530

83. Vieth R. Vitamin D supplementation, 25-hydroxyvitamin D concentrations, and safety. Am J Clin Nutr. (1999) 69:842-56. doi: 10.1093/ajcn/69.5.842

84. Kupferschmidt K. Uncertain verdict as vitamin D goes on trial. Science (2012) 337:1476-8. doi: 10.1126/science.337.6101.1476

85. Pilz S, Rutters F, Dekker JM. Disease prevention: vitamin D trials. Science (2012) 338:883. doi: 10.1126/science.338.6109.883-c

86. Lappe J, Watson P, Travers-Gustafson D, Recker R, Garland C, Gorham E, et al. Effect of vitamin D and calcium supplementation on cancer incidence in older women: a randomized clinical trial. JAMA (2017) 317:1234-3. doi: 10.1001/jama.2017.2115

87. Scragg R, Stewart AW, Waayer D, Lawes CMM, Toop L, Sluyter J, et al. Effect of monthly high-dose vitamin D supplementation on cardiovascular disease in the vitamin D assessment study : a randomized clinical trial. JAMA Cardiol. (2017) 2:608-16. doi: 10.1001/jamacardio.2017.0175

88. Zittermann A, Ernst JB, Prokop S, Fuchs U, Dreier J, Kuhn J, et al. Effect of vitamin D on all-cause mortality in heart failure (EVITA): a 3-year randomized clinical trial with 4000 IU vitamin D daily. Eur Heart J. (2017) 38:2279-86. doi: 10.1093/eurheartj/ehx235

89. Pilz S, Gaksch M, Kienreich K, Grübler M, Verheyen N, Fahrleitner-Pammer A, et al. Effects of vitamin D on blood pressure and cardiovascular risk factors: a randomized controlled trial. Hypertension (2015) 65:1195-201. doi: 10.1161/HYPERTENSIONAHA.115.05319

90. Bischoff-Ferrari HA, Dawson-Hughes B, Orav EJ, Staehelin HB, Meyer OW, Theiler R, et al. Monthly high-dose vitamin D treatment for the prevention of functional decline: a randomized clinical trial. JAMA Intern Med. (2016) 176:175-83. doi: 10.1001/jamainternmed.2015.7148

91. Jorde R, Sollid ST, Svartberg J, Schirmer H, Joakimsen RM, Njølstad I, et al. Vitamin D 20,000 IU per week for five years does not prevent progression from prediabetes to diabetes. J Clin Endocrinol Metab. (2016) 101:1647-55. doi: 10.1210/jc.2015-4013

92. Wacker M, Holick MF. Sunlight and vitamin D: a global perspective for health. Dermatoendocrinol. (2013) 5:51-108. doi: 10.4161/derm.24494

93. Hart A, Hoekstra J, Owen H, Kennedy M, Zeilmaker MJ, de Jong N, et al. Qalibra: a general model for food risk-benefit assessment that quantifies variability and uncertainty. Food Chem Toxicol. (2013) 54:4-17. doi: 10.1016/j.fct.2012.11.056

94. Tijhuis MJ, de Jong N, Pohjola MV, Gunnlaugsdóttir H, Hendriksen M, Hoekstra J, et al. State of the art in benefit-risk analysis: food and nutrition. Food Chem Toxicol. (2012) 50:5-25. doi: 10.1016/j.fct.2011.06.010

95. Hoekstra J, Verkaik-Kloosterman J, Rompelberg C, van Kranen H, Zeilmaker $\mathrm{M}$, Verhagen $\mathrm{H}$, et al. Integrated risk-benefit analyses: method development with folic acid as example. Food Chem Toxicol. (2008) 46:893-909. doi: 10. 1016/j.fct.2007.10.015

96. Meltzer HM, Aro A, Andersen NL, Koch B, Alexander J. Risk analysis applied to food fortification. Public Health Nutr. (2003) 6:281-91. doi: 10.1079/ PHN2002444

97. Schlingmann KP, Kaufmann M, Weber S, Irwin A, Goos C, John U, et al. Mutations in CYP24A1 and idiopathic infantile hypercalcemia. N Engl J Med. (2011) 365:410-21. doi: 10.1056/NEJMoa1103864

98. Pronicka E, Ciara E, Halat P, Janiec A, Wójcik M, Rowinska E, et al. Biallelic mutations in CYP24A1 or SLC34A1 as a cause of infantile idiopathic hypercalcemia (IIH) with vitamin D hypersensitivity: molecular study of 11 historical IIH cases. J Appl Genet. (2017) 58:349-53. doi: 10.1007/s13353-017-0397-2

99. Calvo MS, Whiting SJ, Barton CN. Vitamin D fortification in the United States and Canada: current status and data needs. Am J Clin Nutr. (2004) 80:1710S-6S. doi: 10.1093/ajcn/80.6.1710S

100. Calvo MS, Whiting SJ. Survey of current vitamin D food fortification practices in the United States and Canada. J Steroid Biochem Mol Biol. (2013) 136:211-3. doi: 10.1016/j.jsbmb.2012.09.034

101. Cashman KD, Kiely M. Tackling inadequate vitamin D intakes within the population: fortification of dairy products with vitamin $\mathrm{D}$ may not be enough. Endocrine (2016) 51:38-46. doi: 10.1007/s12020-015-0711-x

102. Wilson LR, Tripkovic L, Hart KH, Lanham-New SA. Vitamin D deficiency as a public health issue: using vitamin D2 or vitamin D3 in future fortification strategies. Proc Nutr Soc. (2017) 76:392-9. doi: 10.1017/S0029665117000349

103. Yeh EB, Barbano DM, Drake M. Vitamin fortification of fluid milk. J Food Sci. (2017) 82:856-64. doi: 10.1111/1750-3841.13648

104. Hennessy Á, Walton J, Flynn A. The impact of voluntary food fortification on micronutrient intakes and status in European countries: a review. Proc Nutr Soc. (2013) 72:433-40. doi: 10.1017/S002966511300339X

105. Jääskeläinen T, Itkonen ST, Lundqvist A, Erkkola M, Koskela T, Lakkala $\mathrm{K}$, et al. The positive impact of general vitamin $\mathrm{D}$ food fortification policy on vitamin $\mathrm{D}$ status in a representative adult Finnish population: evidence from an 11-y follow-up based on standardized 25-hydroxyvitamin D data. Am J Clin Nutr. (2017) 105:1512-20. doi: 10.3945/ajcn.116.151415 
106. Lehtonen-Veromaa M, Möttönen T, Leino A, Heinonen OJ, Rautava E, Viikari J. Prospective study on food fortification with vitamin D among adolescent females in Finland: minor effects. Br J Nutr. (2008) 100:418-23. doi: 10.1017/S0007114508894469

107. Välimäki VV, Löyttyniemi E, Välimäki MJ. Vitamin D fortification of milk products does not resolve hypovitaminosis D in young Finnish men. Eur J Clin Nutr. (2007) 61:493-7. doi: 10.1038/sj.ejcn.1602550

108. Laaksi IT, Ruohola JP, Ylikomi TJ, Auvinen A, Haataja RI, Pihlajamäki $\mathrm{HK}$, et al. Vitamin D fortification as public health policy: significant improvement in vitamin D status in young Finnish men. Eur J Clin Nutr. (2006) 60:1035-8. doi: 10.1038/sj.ejen.1602414

109. Piirainen T, Laitinen K, Isolauri E. Impact of national fortification of fluid milks and margarines with vitamin $\mathrm{D}$ on dietary intake and serum 25hydroxyvitamin D concentration in 4-year-old children. Eur J Clin Nutr. (2007) 61:123-8. doi: 10.1038/sj.ejcn.1602506

110. Pietinen P, Männistö S, Valsta LM, Sarlio-Lähteenkorva S. Nutrition policy in Finland. Public Health Nutr. (2010) 13:901-6. doi: $10.1017 /$ S1368980010001072

111. Raulio S, Erlund I, Männistö S, Sarlio-Lähteenkorva S, Sundvall J, Tapanainen H, et al. Successful nutrition policy: improvement of vitamin D intake and status in Finnish adults over the last decade. Eur J Public Health (2017) 27:268-73. doi: 10.1093/eurpub/ckw154

112. Black LJ, Walton J, Flynn A, Cashman KD, Kiely M. Small increments in vitamin $\mathrm{D}$ intake by irish adults over a decade show that strategic initiatives to fortify the food supply are needed. J Nutr. (2015) 145:969-76. doi: 10.3945/jn.114.209106

113. EC (2009) Commission Regulation (EC) No 1170/2009 of 30 November 2009 amending Directive 2002/46/EC of the European Parliament and of Council and Regulation (EC) No 1925/2006 of the European Parliament and of the Council as regards the lists of vitamin and minerals and their forms that can be added to foods, including food supplements. Official J Eur Union (2009) L314:36-42.

114. EC (2006) Regulation (EC) No 1925/2006 of the European parliament and of the Council of 20 December 2006 on addition of vitamins and minerals and of certain other substances to foods. Official J Eur Union (2006) L404:28-38.

115. Munasinghe LL, Willows ND, Yuan Y, Ekwaru JP, Veugelers PJ. Vitamin D Sufficiency of Canadian Children Did Not Improve Following the 2010 Revision of the dietary guidelines that recommend higher intake of vitamin D: an analysis of the canadian health measures survey. Nutrients (2017) 9:E945. doi: 10.3390/nu9090945

116. Munasinghe LL, Yuan Y, Willows ND, Faught EL, Ekwaru JP, Veugelers PJ. vitamin $\mathrm{D}$ deficiency and sufficiency among Canadian children residing at high latitude following the revision of the RDA of vitamin D intake in 2010. Br J Nutr. (2017) 117:457-65. doi: 10.1017/S0007114517000320

117. Ahluwalia N, Herrick KA, Rossen LM, Rhodes D, Kit B, Moshfegh A, et al. Usual nutrient intakes of US infants and toddlers generally meet or exceed Dietary Reference Intakes: findings from NHANES 2009-2012. Am J Clin Nutr. (2016) 104:1167-74. doi: 10.3945/ajcn.116.137752

118. Avaiilable online at: http://www.fda.gov/Food/IngredientsPackaging Labeling/FoodAdditivesIngredients/ucm510522.htm

119. Smith G. Micronutrient fortification of food: issues for Asia. J Nutr Sci Vitaminol (Tokyo) (2015) 61(Suppl):S183-5. doi: 10.3177/jnsv.61.S183

120. G R, Gupta A. Fortification of foods with vitamin D in India: strategies targeted at children. J Am Coll Nutr. (2015) 34:263-72. doi: 10.1080/07315724.2014.924450

121. G R, Gupta A. Fortification of foods with vitamin D in India. Nutrients (2014) 6:3601-23. doi: 10.3390/nu6093601

122. O’Donnell S, Cranney A, Horsley T, Weiler HA, Atkinson SA, Hanley $\mathrm{DA}$, et al. Efficacy of food fortification on serum 25-hydroxyvitamin D concentrations: systematic review. Am J Clin Nutr. (2008) 88:1528-34. doi: 10.3945/ajcn.2008.26415

123. Black LJ, Seamans KM, Cashman KD, Kiely M. An updated systematic review and meta-analysis of the efficacy of vitamin $\mathrm{D}$ food fortification. $J$ Nutr. (2012) 142:1102-8. doi: 10.3945/jn.112.158014

124. Guo J, Lovegrove JA. Givens DI. 25(OH)D3-enriched or fortified foods are more efficient at tackling inadequate vitamin D status than vitamin D3. Proc Nutr Soc. (2017) 27:1-10. doi: 10.1017/S00296651170 04062
125. Cashman KD, Kazantzidis A, Webb AR, Kiely M. An Integrated predictive model of population serum 25-hydroxyvitamin D for application in strategy development for vitamin D deficiency prevention. J Nutr. (2015) 145:241925. doi: 10.3945/jn.115.217968

126. O’Neill CM, Kazantzidis A, Kiely M, Cox L, Meadows S, Goldberg $\mathrm{G}$, et al. A predictive model of serum 25-hydroxyvitamin D in UK white as well as black and Asian minority ethnic population groups for application in food fortification strategy development towards vitamin D deficiency prevention. J Steroid Biochem Mol Biol. (2017) 173:245-52. doi: 10.1016/j.jsbmb.2016.09.010

127. Taylor CL, Bailey RL, Carriquiry AL. Use of folate-based and other fortification scenarios illustrates different shifts for tails of the distribution of serum 25-hydroxyvitamin D concentrations. J Nutr. (2015) 145:16239. doi: 10.3945/jn.115.211185

128. Cashman KD, van den Heuvel EG, Schoemaker RJ, Prévéraud DP, Macdonald HM, Arcot J. 25-Hydroxyvitamin D as a biomarker of vitamin $\mathrm{D}$ status and its modeling to inform strategies for prevention of vitamin D deficiency within the population. Adv Nutr. (2017) 8:947-57. doi: 10.3945/an.117.015578

129. Harika RK, Dötsch-Klerk M, Zock PL, Eilander A. Compliance with dietary guidelines and increased fortification can double vitamin D intake: a simulation study. Ann Nutr Metab. (2016) 69:246-55.

130. Grønborg IM, Tetens I, Ege M, Christensen T, Andersen EW, Andersen R. Modelling of adequate and safe vitamin D intake in Danish women using different fortification and supplementation scenarios to inform fortification policies. Eur J Nutr. (2018). doi: 10.1007/s00394-017-1586-9. [Epub ahead of print].

131. Ejtahed HS, Shab-Bidar S, Hosseinpanah F, Mirmiran P, Azizi F. Estimation of vitamin D intake based on a scenario for fortification of dairy products with vitamin D in a tehranian population, Iran. J Am Coll Nutr (2016) 35:383-91. doi: 10.1080/07315724.2015.1022269

132. Jayaratne N, Hughes MC, Ibiebele TI, van den Akker S, van der Pols JC. Vitamin D intake in Australian adults and the modeled effects of milk and breakfast cereal fortification. Nutrition (2013) 29:1048-53. doi: 10.1016/j.nut.2013.02.011

133. Brown J, Sandmann A, Ignatius A, Amling M, Barvencik F. New perspectives on vitamin $\mathrm{D}$ food fortification based on a modeling of $25(\mathrm{OH}) \mathrm{D}$ concentrations. Nutr J. (2013) 12:151. doi: 10.1186/1475-2891-12-151

134. Hirvonen T, Sinkko H, Valsta L, Hannila ML, Pietinen P. Development of a model for optimal food fortification: vitamin D among adults in Finland. Eur J Nutr. (2007) 46:264-70. doi: 10.1007/s00394-007-0660-0

135. Tylavsky FA, Cheng S, Lyytikäinen A, Viljakainen H, Lamberg-Allardt C. Strategies to improve vitamin D status in northern European children: exploring the merits of vitamin D fortification and supplementation. J Nutr. (2006) 136:1130-4. doi: 10.1093/jn/136.4.1130

136. Zittermann A, Ernst JB, Gummert JF, Börgermann J. Vitamin D supplementation, body weight and human serum 25-hydroxyvitamin D response: a systematic review. Eur J Nutr. (2014) 53:367-74. doi: 10.1007/ s00394-013-0634-3

137. Fiedler JL, Sanghvi TG, Saunders MK. A review of the micronutrient intervention cost literature: program design and policy lessons. Int J Health Plann Manage. (2008) 23:373-97. doi: 10.1002/hpm.928

138. Aguiar M, Andronis L, Pallan M, Högler W, Frew E. Preventing vitamin $\mathrm{D}$ deficiency (VDD): a systematic review of economic evaluations. Eur J Public Health (2017) 27:292-301. doi: 10.1093/eurpub/ ckw270

139. Sandmann A, Amling M, Barvencik F, König HH, Bleibler F. Economic evaluation of vitamin $\mathrm{D}$ and calcium food fortification for fracture prevention in Germany. Public Health Nutr. (2017) 20:1874-83. doi: $10.1017 /$ S1368980015003171

140. Hiligsmann M, Neuprez A, Buckinx F, Locquet M, Reginster JY. A scoping review of the public health impact of vitamin D-fortified dairy products for fracture prevention. Arch Osteoporos (2017) 12:57. doi: 10.1007/s11657-017-0352-1

141. Ethgen O, Hiligsmann M, Burlet N, Reginster JY. Public health impact and cost-effectiveness of dairy products supplemented with vitamin D in prevention of osteoporotic fractures. Arch Public Health (2015) 73:48. doi: 10.1186/s13690-015-0099-3 
142. Ethgen O, Hiligsmann M, Burlet N, Reginster JY. Cost-effectiveness of personalized supplementation with vitamin D-rich dairy products in the prevention of osteoporotic fractures. Osteoporos Int. (2016) 27:301-8. doi: 10.1007/s00198-015-3319-3

143. Hiligsmann M, Burlet N, Fardellone P, Al-Daghri N, Reginster JY. Public health impact and economic evaluation of vitamin D-fortified dairy products for fracture prevention in France. Osteoporos Int. (2017) 28:833-40. doi: 10.1007/s00198-016-3786-1

144. Hiligsmann M, Reginster JY. The projected public health and economic impact of vitamin D fortified dairy products for fracture prevention in France. Expert Rev Pharmacoecon Outcomes Res. (2018) 18:191-5. doi: 10.1080/14737167.2017.1375406

145. Al-Daghri NM, Al-Saleh Y, Aljohani N, Sulimani R, Al-Othman AM, Alfawaz $\mathrm{H}$, et al. Vitamin $\mathrm{D}$ status correction in Saudi Arabia: an experts' consensus under the auspices of the European Society for Clinical and Economic Aspects of Osteoporosis, Osteoarthritis, and Musculoskeletal Diseases (ESCEO). Arch Osteoporos. (2017) 12:1. doi: 10.1007/s11657-016-0295-y

146. Kamudoni P, Poole C, Davies SJ. An estimate of the economic burden of vitamin D deficiency in pregnant women in the United Kingdom. Gynecol Endocrinol. (2016) 32:592-7. doi: 10.3109/09513590.2016.1160374

147. Poole CD, Smith J, Davies JS. Cost-effectiveness and budget impact of Empirical vitamin D therapy on unintentional falls in older adults in the UK. BMJ Open (2015) 5:e007910. doi: 10.1136/bmjopen-2015-007910

148. Zittermann A. The estimated benefits of vitamin D for Germany. Mol Nutr Food Res. (2010) 54:1164-71. doi: 10.1002/mnfr.200900494

149. Grant WB, Cross HS, Garland CF, Gorham ED, Moan J, Peterlik M, et al. Estimated benefit of increased vitamin D status in reducing the economic burden of disease in western Europe. Prog Biophys Mol Biol. (2009) 99:104-3. doi: 10.1016/j.pbiomolbio.2009.02.003

150. Péter S, Eggersdorfer M, van Asselt D, Buskens E, Detzel P, Freijer K, et al. Selected nutrients and their implications for health and disease across the lifespan: a roadmap. Nutrients (2014) 6:6076-94. doi: 10.3390/nu6126076

151. Hannemann A, Wallaschofski H, Nauck M, Marschall P, Flessa S, Grabe HJ, et al. Vitamin D and health care costs: results from two independent population-based cohort studies. Clin Nutr. (2017). doi: 10.1016/j.clnu.2017.10.014. [Epub ahead of print].

152. Sandmann A, Brown J, Mau G, Suar M, Amling M, Barvencik F. Acceptance of vitamin D-fortified products in Germany - a representative consumer study. Food Qual Prev. (2015) 43:53-62. doi: 10.1016/j.foodqual.2015.02.011

153. Allen L, de Benoist B, Dary O, Hurrell R, editors. Guidelines on Food Fortification with Micronutrients. Geneva; Rome: WHO/Food and Agriculture Organization of the United Nations (2006). Available online at: http://www.who.int/iris/handle/10665/43412

154. Hyppönen E, Läärä E, Reunanen A, Järvelin MR, Virtanen SM. Intake of vitamin D and risk of type 1 diabetes: a birth-cohort study. Lancet (2001) 358:1500-3. doi: 10.1016/S0140-6736(01)06580-1

155. Stougaard M, Damm P, Frederiksen P, Jacobsen R, Heitmann BL. Exposure to vitamin $\mathrm{D}$ from fortified margarine during fetal life and later risk of pre-eclampsia: the D-tect Study. Public Health Nutr. (2018) 21:72131. doi: $10.1017 /$ S1368980017003135

156. Jacobsen R, Hypponen E, Sørensen TI, Vaag AA, Heitmann BL Gestational and early infancy exposure to margarine fortified with vitamin $\mathrm{d}$ through a national danish programme and the risk of type 1 diabetes: the $\mathrm{D}$-tect study. PLoS ONE (2015) 10:e0128631. doi: 10.1371/journal.pone.0128631

157. Brannon PM, Mayne ST, Murphy SP, Taylor CL. Vitamin D supplementation in African Americans: dose-response. Am J Clin Nutr. (2014) 100:982-4. doi: $10.3945 /$ ajcn.114.090605

158. Rabenberg M, Scheidt-Nave C, Busch MA, Rieckmann N, Hintzpeter B, Mensink GB. Vitamin D status among adults in Germany-results from the German Health Interview and Examination Survey for Adults (DEGS1). BMC Public Health (2015) 15:641. doi: 10.1186/s12889-015-2016-7

159. Hintzpeter B, Mensink GB, Thi erfelder W, Müller MJ, Scheidt-Nave C. Vitamin D status and health correlates among German adults. Eur J Clin Nutr. (2008) 62:1079-89. doi: 10.1038/sj.ejcn.1602825

160. Hintzpeter B, Scheidt-Nave C, Müller MJ, Schenk L, Mensink GBM. Higher prevalence of vitamin $\mathrm{D}$ deficiency is associated with immigrant background among children and adolescents in Germany. J Nutr. (2008) 138:1482-90. doi: $10.1093 /$ jn/138.8.1482

161. Kudlacek S, Schneider B, Peterlik M, Leb G, Klaushofer K, Weber K, et al. Assessment of vitamin D and calcium status in healthy adult Austrians. Eur J Clin Invest. (2003) 33:323-31. doi: 10.1046/j.1365-2362.2003. 01127.x

162. Elmadfa I, Meyer AL, Wottawa D, Wagner K, Hasenegger V. Vitamin D intake and status in austria and its effects on some health indicators. Austin J Nutr Metab. (2017) 4:1050.

163. Austrian Nutrition Report 2012. Available online at: https://www.bmgf.gv. at/cms/home/attachments/4/5/3/CH1048/CMS1348749794860/oeb12.pdf

164. Austrian Nutrition Report 2017. Available online at: https://www.bmgf.gv. at/home/Ernaehrungsbericht 2017

165. Wagner KH, Blauensteiner D, Schmid I, Elmadfa I. The role of fortified foods-situation in Austria. Forum Nutr. (2005) 57:84-90. doi: 10.1159/000083771

166. Pilz S, Hahn A, Schön C, Wilhelm M, Obeid R. Effect of two different multimicronutrient supplements on vitamin $\mathrm{d}$ status in women of childbearing age: a randomized trial. Nutrients (2017) 9:30. doi: $10.3390 /$ nu 9010030

167. Gellert S, Ströhle A, Bitterlich N, Hahn A. Higher prevalence of vitamin D deficiency in German pregnant women compared to non-pregnant women. Arch Gynecol Obstet (2017) 296:43-51. doi: 10.1007/s00404-0174398-5

168. Stahl A, Vohmann C, Richter A, Heseker H, Mensink GB. Changes in food and nutrient intake of 6- to 17-year-old Germans between the 1980s and 2006. Public Health Nutr. (2009) 12:1912-23. doi: $10.1017 /$ S1368980009004844

169. Singh GM, Micha R, Khatibzadeh S, Shi P, Lim S, Andrews KG, et al. Global, Regional, and National Consumption of Sugar-Sweetened Beverages, Fruit Juices, and Milk: A Systematic Assessment of Beverage Intake in 187 Countries. PLoS ONE (2015) 10:e0124845. doi: 10.1371/journal.pone.0124845

170. Płudowski P, Ducki C, Konstantynowicz J, Jaworski M. Vitamin D status in Poland. Pol Arch Med Wewn. (2016) 126:530-9. doi: 10.20452/pamw.3479

171. Pludowski P, Grant WB, Bhattoa HP, Bayer M, Povoroznyuk V, Rudenka E, et al. Vitamin d status in central europe. Int J Endocrinol. (2014) 2014:589587. doi: $10.1155 / 2014 / 589587$

172. Cashman KD, Ritz C, Kiely M, Odin Collaborators. Improved Dietary Guidelines for Vitamin D: Application of Individual Participant Data (IPD)-Level Meta-Regression Analyses. Nutrients (2017) 9:E469. doi: 10.3390/nu9050469

173. Rasmussen SE, Andersen NL, Dragsted LO, Larsen JC. A safe strategy for addition of vitamins and minerals to foods. Eur J Nutr. (2006) 45:123-35. doi: 10.1007/s00394-005-0580-9

174. Tarausk V. Discretionary Fortification-a public health perspective. Nutrients (2014 ) 6:4421-33. doi: 10.3390/nu6104421

175. Datta M, Vitolins MZ. Food Fortification and Supplement Use-Are There Health Implications? Crit Rev Food Sci Nutr. (2016) 56:2149-59. doi: 10.1080/10408398.2013.818527

176. Cashman KD. Vitamin D requirements for the future-lessons learned and charting a path forward. Nutrients (2018) 10:533. doi: 10.3390/nu10050533

Conflict of Interest Statement: The authors declare that the research was conducted in the absence of any commercial or financial relationships that could be construed as a potential conflict of interest.

Copyright (c 2018 Pilz, März, Cashman, Kiely, Whiting, Holick, Grant, Pludowski, Hiligsmann, Trummer, Schwetz, Lerchbaum, Pandis, Tomaschitz, Grübler, Gaksch, Verheyen, Hollis, Rejnmark, Karras, Hahn, Bischoff-Ferrari, Reichrath, Jorde, Elmadfa, Vieth, Scragg, Calvo, van Schoor, Bouillon, Lips, Itkonen, Martineau, Lamberg-Allardt and Zittermann. This is an open-access article distributed under the terms of the Creative Commons Attribution License (CC BY). The use, distribution or reproduction in other forums is permitted, provided the original author(s) and the copyright owner(s) are credited and that the original publication in this journal is cited, in accordance with accepted academic practice. No use, distribution or reproduction is permitted which does not comply with these terms. 